\title{
Sustainability Assessment of Randullabad Watershed in Satara District of Maharashtra State, India
}

\author{
Bharat K Kakade ${ }^{1} \&$ Sneha A Shinde ${ }^{1}$ \\ ${ }^{1}$ BAIF Development Research Foundation, Warje, Pune, India \\ Correspondence: Bharat Kakade, BAIF Development Research Foundation, Warje, Pune, Maharashtra, India. Tel: \\ 91-94-2350-7335. E-mail: bkkakade@baif.org.in
}

Received: April 10, 2019

doi:10.5539/jsd.v12n3p103
Accepted: April 28, 2019 Online Published: May 30, 2019

URL: https://doi.org/10.5539/jsd.v12n3p103

\begin{abstract}
Sustainability of watersheds being a major issue in India Kakade, 2017 proposed a new comprehensive framework and methodology for sustainability assessment of watersheds, which would also help design sustainable watershed projects. This new methodology was validated undertaking in-depth critical assessment of an integrated watershed development project implemented by Randullabad village Grampanchayat (Note 1) under the facilitation of BAIF (Note 2). Project of 836 ha area and 394 households was implemented during 2008 to 2013. The assessment was carried out to find out sustainability of social, economic and ecological domains at the baseline (2008), at project completion (2013) and five years after completion (2017-18). The indicators used in the framework and methodology by Kakade, 2017 was validated and the final framework emerged through the study has been presented in the paper. Rising trends of sustainability scores in all three domains were observed from inception to completion of project and also five years after completion. Key contributing factors for sustainability include the project design, community empowerment, post-project maintenance, governance and role of facilitating organizations.
\end{abstract}

Keywords: watershed sustainability, sustainability assessment framework and methodology, social, economic and ecological sustainability indicators

\section{Introduction}

The definition used in Brundtland Commission's report 'Our Common Future' (1987) was a turning point from previous inclination of "growth or environment" towards complimenting each other the "economic growth and environment". The concept emphasizes not only quantity and quality of economic growth and people's well-being (Ciegis, 2009). Caring for natural resources and promoting their sustainable use is an essential response to the world community to ensure its survival and wellbeing". This is quite closer to the sustainability needs of developed watersheds. If this logic is applied for developed watersheds, watershed will be sustainable if it provides economic growth along with enriched environment and management systems for future generations. "The management of watershed system with sustainable technological options, which may ensure the sustainability of land, agriculture and forestry or its combinations to conserve natural resources with adequate institutional and economic options" (Vishnudas, at. al., 2005). The developed watersheds can be called as sustainable if the resource base created continues to provide additional productivity without depletion or deterioration of the resources.

\subsection{Issues of Watershed Programme Sustainability}

The results of watershed projects in improving the production, economic growth and environmental conservation have been good (Sharda, et.al., 2005; Reddy and Ravindra, 2004; Chaturvedi, 2005; Lobo, 1996). However, sustainability is a major concern across all national or state programmes A meta-analysis 311 case studies of watersheds in India report the silent revolution in rainfed areas but also pointed out its failure of sustainability due to lack of institutional mechanism (Joshi. P. K., et.al., 2005). A watershed can be considered to have physically and socially sustainable resource use, management and governance if the reach of benefits is gained by all sections of community. Uncontrolled use of natural resources after the implementation phase of watershed development; dis-integration or defunct people's institutions, unresolved conflicts among different factions within the community are some indicators of weak management and governance (Keremane, et.al., 2006). 
The sustenance of the projects can be attributed to capacity building of local institutions (Arya and Samra 2001) and empowerment of committees. The role of favorable political and policy regime is also important. Water resource development, management, maintenance or use is not considered as an important activity, as there are no systems in place to ensure that the management and maintenance is taken care of, after the project.

Many of the watersheds have hierarchy of benefits and beneficiaries; the farmers with access to irrigation benefit the most while others get only the incremental benefits due to soil conservation. Due to this skewed distribution of benefits Sharma (2005), suggests need of placing these issues at the center of participatory process and initiating the negotiations among different beneficiaries and stakeholders.

Kakade, 2017 developed a new methodology for assessment of sustainability as well to help design the watershed projects which can incorporate the interventions contributing to sustainability. The methodology developed was validated using it for sustainability assessment of Randullabad project.

\subsection{Study Objective}

To undertake in-depth sustainability assessment of Randullabad watershed to understand the elements of sustainability

\subsection{Profile of Randullabad Watershed}

Randullabad is a dry, semi-arid, rainfed watershed. It is located between Latitudes $17^{0} 50^{\prime} \mathrm{E}$ to $18^{0} 05^{\prime} \mathrm{E}$ and Longitudes of $74^{0} 10^{\prime} \mathrm{N}$ to $74^{0} 20^{\prime} \mathrm{N}$ in Satara district of Maharashtra state in India. Figure 1 shows the location of Randullabad watershed.

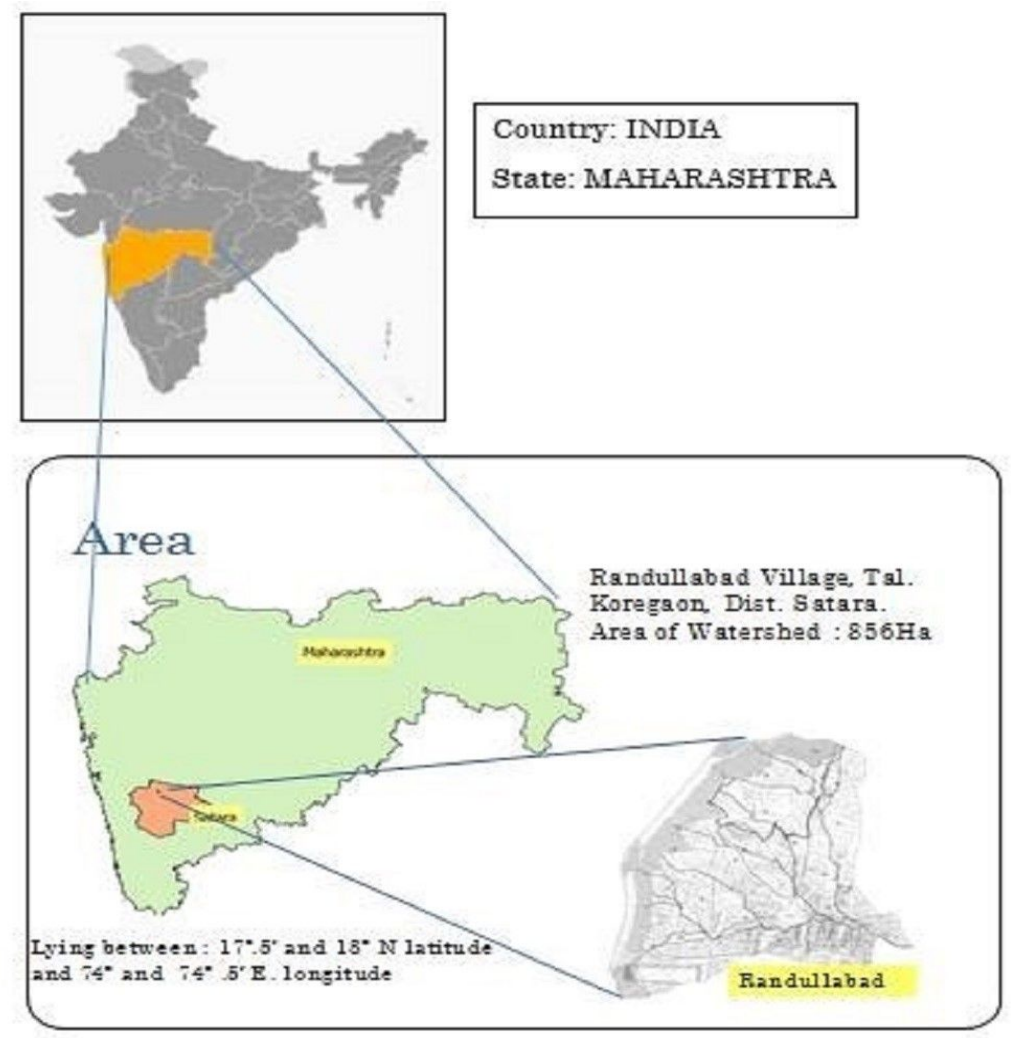

Figure 1. Location Map of Randullabad watershed

The topography of watershed is undulating with the highest elevation of $1134 \mathrm{~m}$ and lowest elevation of $860.00 \mathrm{~m}$, above the mean sea level. The watershed is drained by three major streams and their tributaries. The whole drainage system is the part of the Krishna river basin. All these streams are seasonal and retain some flow until January month.

\subsubsection{Rainfall Pattern}

The data of Koregaon rain gauge station has been obtained for the period from 1999 to 2017 . The annual average rainfall of Koregaon station for this period is $668.49 \mathrm{~mm}$. The Rainguage station was established in Randullabad 
village in the year 2010, so the records from 2010 till 2017 shows the average annual rainfall of $648.40 \mathrm{~mm}$, slightly less than that of Koregaon, which is $38 \mathrm{~km}$ away. This indicates that Randullabad is a drought prone village and rainfall pattern is irregular. Figure 2 shows that the highest recorded rainfall was $1097.52 \mathrm{~mm}$ in 2010 while 2014 saw the lowest rainfall of $362.7 \mathrm{~mm}$.

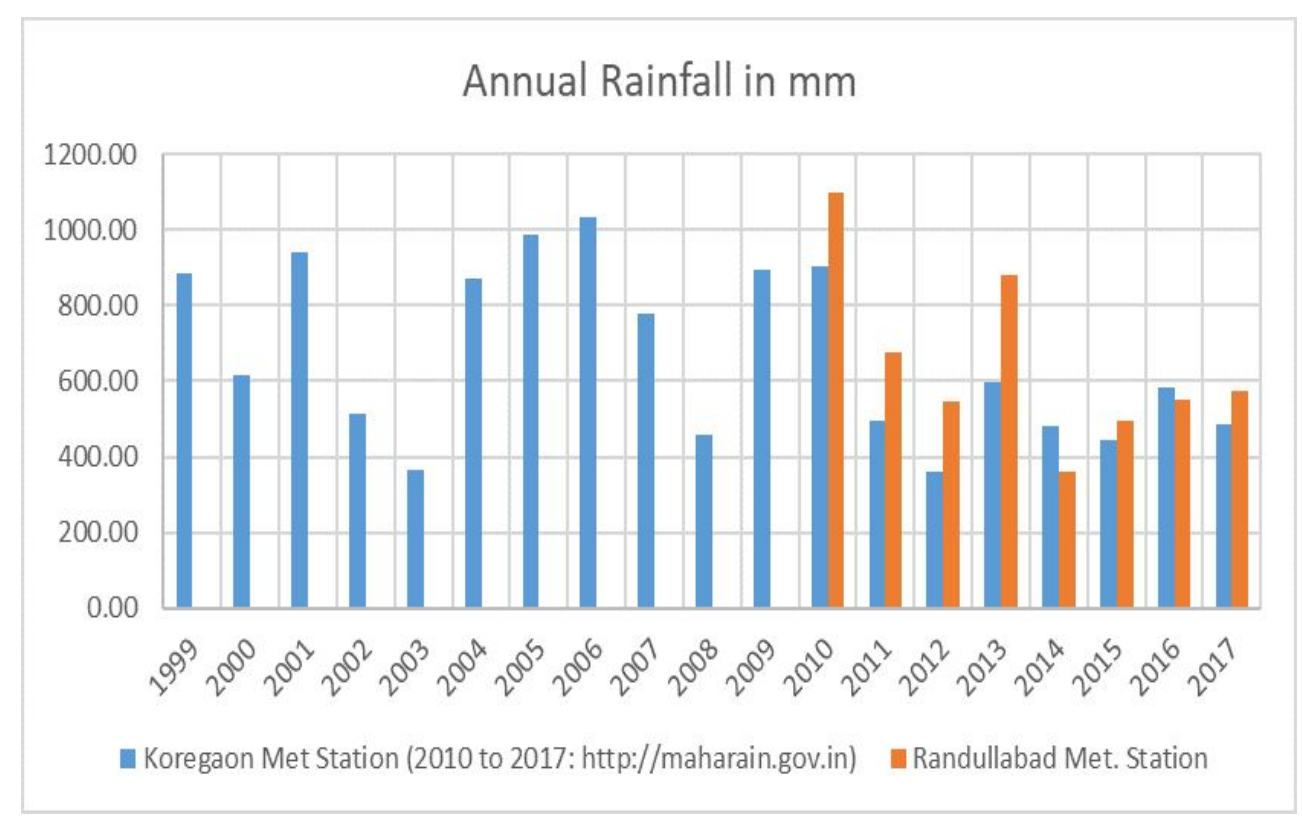

Figure 2. Rainfall Pattern of Randullabad Watershed

\subsubsection{Socio Economy}

Randullabad is a medium size village with total 394 families. It has population of 1857 of which 914 are males, while 943 are females.

Average Sex Ratio of Randullabad village is 1032 , which is higher than Maharashtra state average of 929. Child Sex Ratio in Randullabad as per census is 1143 , higher than Maharashtra average of 894. Out of the total population, 580 are engaged in work activities. Of this, $90.69 \%$ workers describe their work as Main Work while $9.31 \%$ are involved in marginal activity providing a livelihood for less than 6 months. The primary occupation in the village is farming.

\subsubsection{Land holding Pattern of Randullabad}

The landholding pattern of Randullabad watershed is as given in Table 1. Majority of the farmers are small and marginal land-holders. Landless (3\%), small and marginal land-holders form $85 \%$ of the population. There are just 2 farmers holding above 8ha land. Land-fragmentation was also observed in Randullabad.

Table 1. Land holding pattern of Randullabad

\begin{tabular}{lll}
\hline \multirow{2}{*}{ Land holding class (ha) } & \multicolumn{2}{c}{ Total Households } \\
\cline { 2 - 3 } & Year 2008 & Year 2018 \\
\hline Landless & 14 & 12 \\
$1<1$ & 183 & 147 \\
$2<4$ & 134 & 178 \\
$4<8$ & 34 & 44 \\
More than 8 & 8 & 11 \\
Total & 1 & 2 \\
\end{tabular}




\subsubsection{Caste-Wise Household Distribution}

Table 2 shows the caste-wise number of households in the watershed. The open category households (81.4\%) form the majority of population in the village. In the year 2018, the Schedule Caste (SC) constituted $5.3 \%$ while Schedule Tribe (ST) were $0.76 \%$ of the total population. Other Backward Caste (OBC) community was $12.18 \%$. There was also a single household of Nomadic Tribe (NT).

Table 2. Caste wise household distribution

\begin{tabular}{lll}
\hline Caste/ Population & Year 2008 & Year 2018 \\
\hline Scheduled Caste (SC) & 16 & 21 \\
Scheduled Tribe (ST) & 2 & 3 \\
Nomadic Tribe (NT) & 1 & 1 \\
Other Backward Class (OBC) & 36 & 48 \\
Open & 319 & 321 \\
TOTAL & 374 & 394 \\
\hline
\end{tabular}

\subsubsection{Education}

Randullabad has a higher literacy rate compared to Maharashtra. The literacy rate is $86.94 \%$ as compared to $82.34 \%$ of Maharashtra. The male literacy stands at $92.71 \%$ while the female literacy rate was $81.29 \%$ (Census, 2011). Illiterate people have been reduced from $8 \%$ in 2008 to $4 \%$ in 2018 . That's a good trend. Shift towards higher education is observed from the figure 3 .

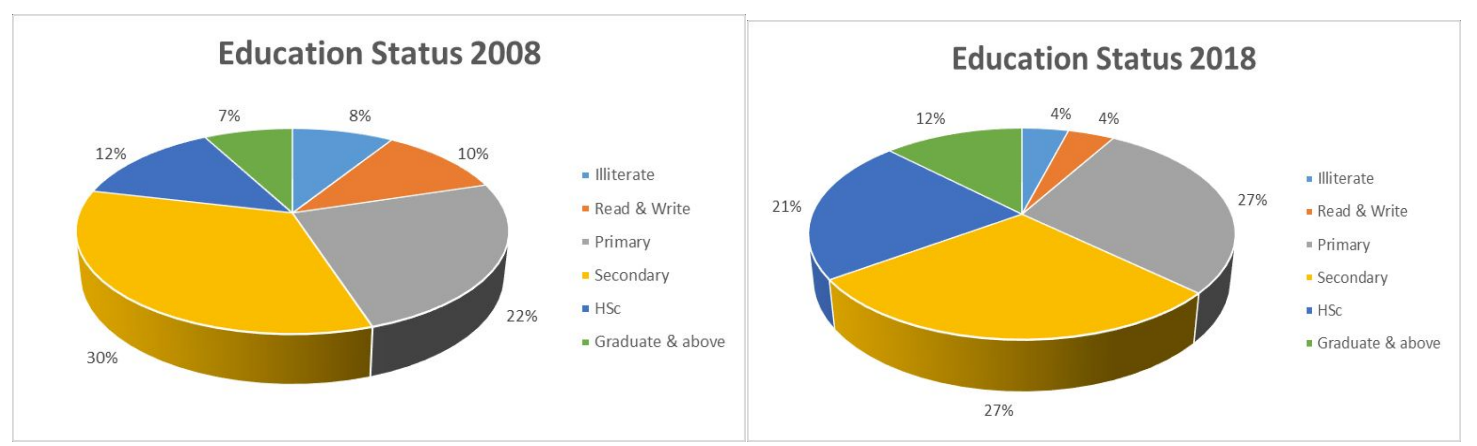

Figure 3. Education status of sample households

\subsection{Main Issues in Randullabad}

Issues Identified at the baseline (2008) of the project were as under:

1) Randullabad is a drought affected village, falling in the rain shadow region of the Sahyadris. The drought zone suffers from uncertain rainfall in the range of 500 to $750 \mathrm{~mm}$. Water scarcity for both agriculture and domestic purposes. Village required tanker water during summer season every year.

2) The uncertainty of rainfall leads to unplanned cropping patterns and constraints to accept and carry on with the poor harvest or many times crop failure.

3) Deforestation supported soil loss on account of un-hurdled runoff of rain water.

4) The decrease in agricultural produce, which resulted in inadequate subsistence provision for the villagers.

5) Temporary migration from rural to urban for their livelihood.

\subsection{Project Components}

Randullabad project represents a typical watershed development project. It included quality of life measures and livelihood measures for both land holding households and landless. Watershed development project implemented with a participatory approach during the year 2008-13. The activities were focused under three main categoriesconservation measures, livelihood measures and social development The main activities implemented during the project are mentioned below: 


\section{Natural Resource Conservation Measures}

i. Soil and Water Conservation

ii. Afforestation

iii. Crop Cultivation

iv. Drainage Line Treatment

\section{Livelihood Measures}

i. Dry Land Horticulture

ii. Agro Horticulture

iii. Dairy Husbandry

iv. Income generation activities

\section{Social - Community Awareness and Institutions}

i. Community awareness and stakeholder engagement

ii. Formation and Strengthening of Village Watershed Committee (VWC)

iii. Formation and Strengthening of Self Help Groups (SHGs) \& Sanyukta Mahila Samitti (SMS)- Women's Federation

iv. Drudgery Reduction Activities

The details of project activities and expenditure through the project is provided in Appendix A. Map in figure 4 shows the project activities under IGWDP Phase-III.

In addition to these, VWC undertook activities including drinking water supply and sanitation, cleanliness, farm ponds, weather recording and other village development measures through convergence of ongoing Govt. programmes.

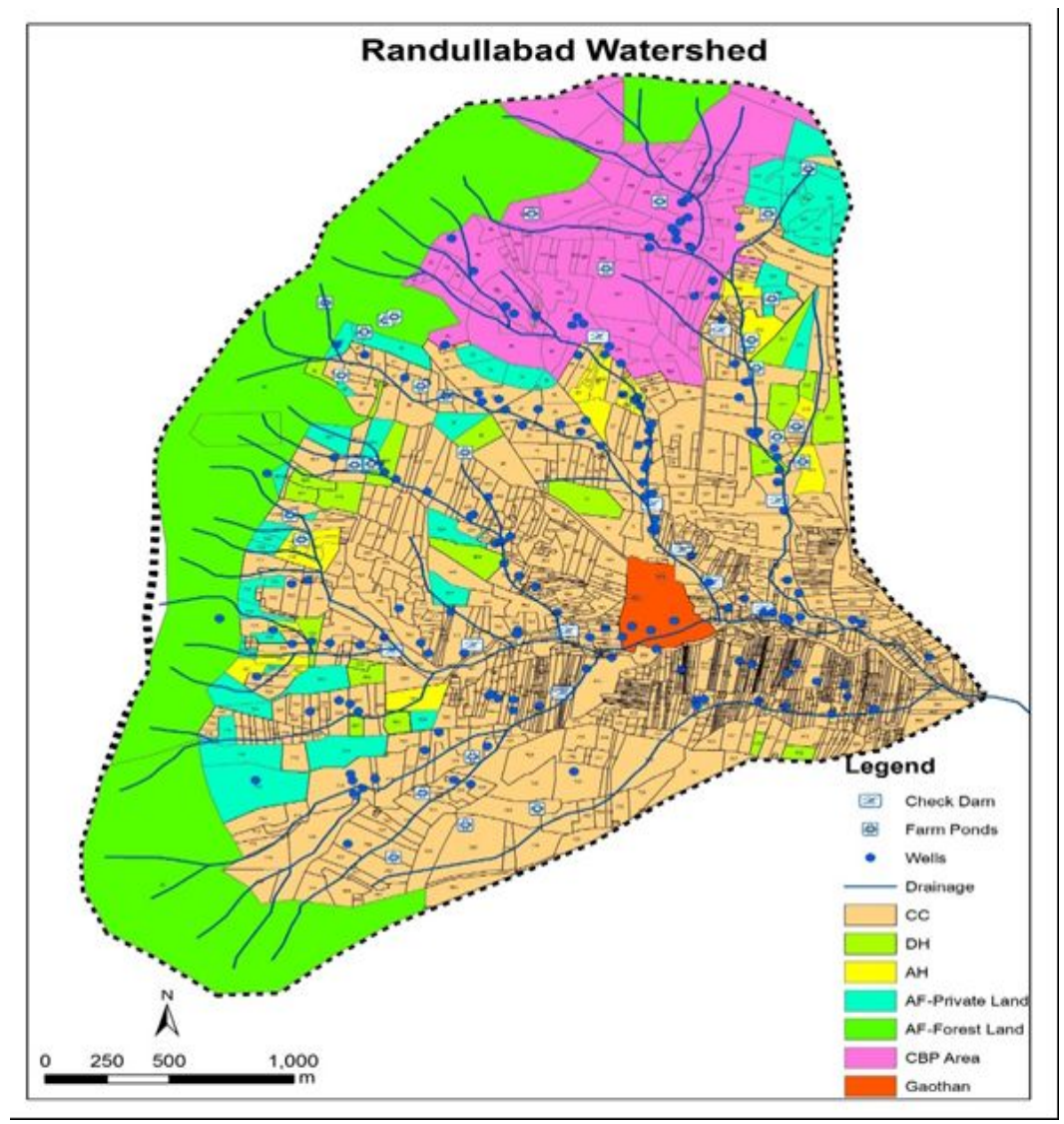

Figure 4. Watershed treatment measures of Randullabad 


\section{Method}

The profile of Randullabad watershed is provided in Table 3 .

Table 3. Profile of Randullabad Watershed

\begin{tabular}{ll}
\hline Name of Watershed & Randullabad \\
\hline Taluka, District and State & Taluka- Koregaon, District - Satara, State - Maharashtra \\
Name of the project & Indo German Watershed Development Programme (IGWDP) \\
Funded by & KFW Germany through NABARD \\
Project Implementing Agency (PIA) & Gram-panchayat of Randullabad \\
Village Watershed Committee & Jai Hanuman Panlot Kshetra Vikas Sanstha, Randullabad \\
Project Period & 2008 to 2013 \\
Total Geographical Area (ha) & 836 ha \\
Total treated Area (ha) & 732 ha \\
Total Number of households & 374 in the year 2008 and 394 in 2018 \\
\hline
\end{tabular}

\subsection{Study Methodology}

Research framework of Kakade 2017, has been adopted for sustainability assessment of Randullabad watershed. Field work was conducted during November 2017 to June 2018. Based on the data requirement and expected sources of information, a combination of different tools was used. These include;

i. Secondary data collection

ii. Household socio-economic survey based on pre-decided questionnaire. Out of 394 households, 125 households were randomly selected from the list of households available with Village Watershed Committee (VWC). This is about $30 \%$ of sample size. The data analysis has been done for these 125 households, however, the income data could be analyzed only of 110 households due to inaccuracy and gaps in the data of other households.

iii. The socioeconomic data of the same households (selected for survey in 2017-18) was referred from the baseline survey of project, which was conducted in 2008. This was used for comparison of the status of different indicators at the inception of project and in the year 2017-18.

iv. Site visits to capture and verify the status of water harvesting structures, and other soil conservation measures.

v. Focus Group Discussions with VWC members, villagers, students, dairy board members, Gram Panchayat members, SMS and women SHG members.

vi. The records of VWC including proceedings in minutes book maintained by VWC, transactions of maintenance fund, the records of baseline surveys, village profile and watershed treatment measures were verified.

vii. BAIF and VWC records on the projects activities, convergence activities, meteorological data, groundwater data and other reports available with Gram Panchayat and BAIF.

The data has been analyzed for each of the sustainability indicator used in the study framework. The analysis and observations are provided in the succeeding section. Overall assessment of sustainability has been plotted through web-diagram to see the trends of performance of social, economic and ecological parameters.

\section{Sustainability Parameters}

The indicators on sustainability of watershed are categorized under social, economic and ecological parameters are given below: 


\section{Social Sustainability}

1) Community awareness

2) Participatory approach

3) Access to resources

4) Equity: Upstream-downstream, social and gender (inclusion/exclusion)

5) Knowledge, education

6) Conflict management

7) Institutions

i. Institutions and capacities of institutions

ii. Regulatory mechanisms (such as water regulation, forest-land management, role of GP, GS)

iii. Sustainability funds

iv. Implementing organizations

v. Incentives for common pool resource management

vi. Management of private and common lands

vii. Externalities (such as political, bureaucratic, surrounding villages, market forces)

\section{II) Economic Sustainability}

1) Family income

2) Distribution of benefits

3) Migration

4) Human induced capital

5) Farm production and diversification

6) Access to credit

7) Access to market

\section{III) Ecological Sustainability}

1) Soil conservation

2) Siltation in water reservoirs

3) Water -quantity and quality

4) Water use efficiency

5) Ground water status

6) Forestry, biodiversity and stream bank vegetation.

All the indicators in the above list have been evaluated and analyzed. The analysis and observations are presented in the following section.

\section{Results}

As explained in above section, sustainability indicators have been classified into three key domains viz. social, economic and ecological.

\subsection{Social Sustainability}

The field data of indicators under the social sustainability domain have different units. For independent analysis and comparison across the years these units could be used, but for comparison of indicators on a single platform such as web-diagram within the groups as well as across the years, all the indicators had to be converted at a standardised scale. Therefore, the values of indicators used for the social sustainability analysis have been converted into the standardised value on a common scale (mean 0 with a standard deviation of 1 ) as shown in the Table 4. Data standardization is a process, wherein the data is standardized with a mean of zero and standard deviation of one. Each case's value on the standardized variable indicates it's difference from the mean of the original variable in number of standard deviations (of the original variable). It can be better presented in the following formula. 


$$
\text { Xnew }=-\frac{x-\mu}{\sigma}
$$

$[$ New value $=($ Original value - Mean $) /$ Standard Deviation $]$

The indicators in Table 4, landless representation in VWC, SC-ST-NT-OBC representation in VWC and \% Women representation in village Institutions represent the indicator equity. Out of the seven sub-indicators under the main indicator of 'Institutions', resource mobilization by VWC for village development works represents the Institutions and capacities of institutions, Water Efficient Technologies Adopted represents the Regulatory mechanisms and the Sustainability fund created is another sub-indicator. Other indicators couldn't be considered for web-diagram as it was not possible to quantify them. Hence the descriptive analysis is presented separately for these indicators.

Table 4. Standardized values of social indicators

\begin{tabular}{|c|c|c|c|c|c|c|c|c|c|c|c|}
\hline \multirow[b]{2}{*}{ 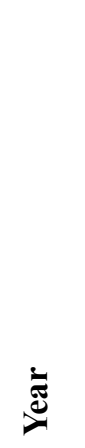 } & \multirow[b]{2}{*}{ 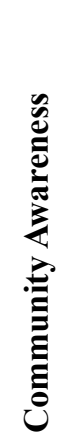 } & \multirow[b]{2}{*}{ 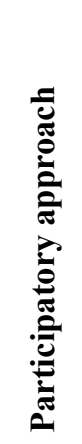 } & \multirow{2}{*}{ 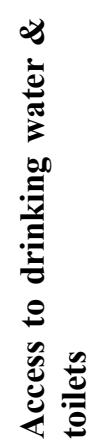 } & \multicolumn{3}{|l|}{ Equity } & \multirow[b]{2}{*}{ 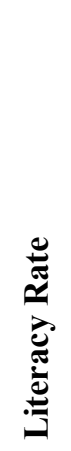 } & \multirow{2}{*}{ 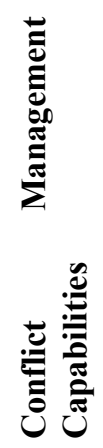 } & \multicolumn{3}{|l|}{ Institutions } \\
\hline & & & & 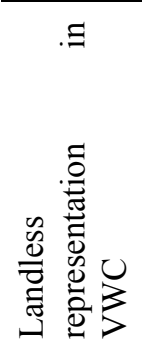 & 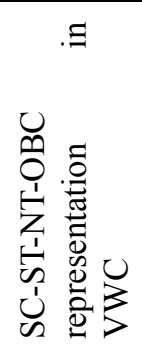 & 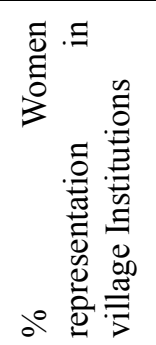 & & & 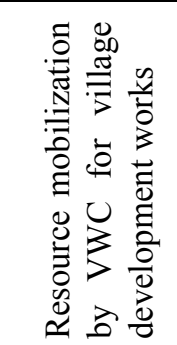 & 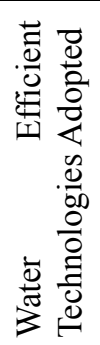 & 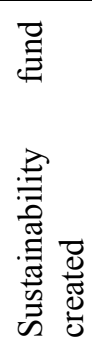 \\
\hline 2008 & -1.1 & -1.1 & -1.1 & -0.6 & -0.6 & -0.9 & -1 & -1.2 & -1.2 & -0.9 & -1.1 \\
\hline 2013 & 0.3 & 0.3 & 0.3 & -0.6 & -0.6 & -0.3 & 0 & 0.6 & 0.4 & -0.3 & 0.2 \\
\hline 2018 & 0.9 & 0.9 & 0.9 & 1.2 & 1.2 & 1.2 & 1 & 0.6 & 0.8 & 1.1 & 0.9 \\
\hline
\end{tabular}

The web diagram constructed on the basis of standardized values of the indicators at the beginning of project (2008), at project completion (2013) and in the year of study (2018) is as presented in figure 5 . 


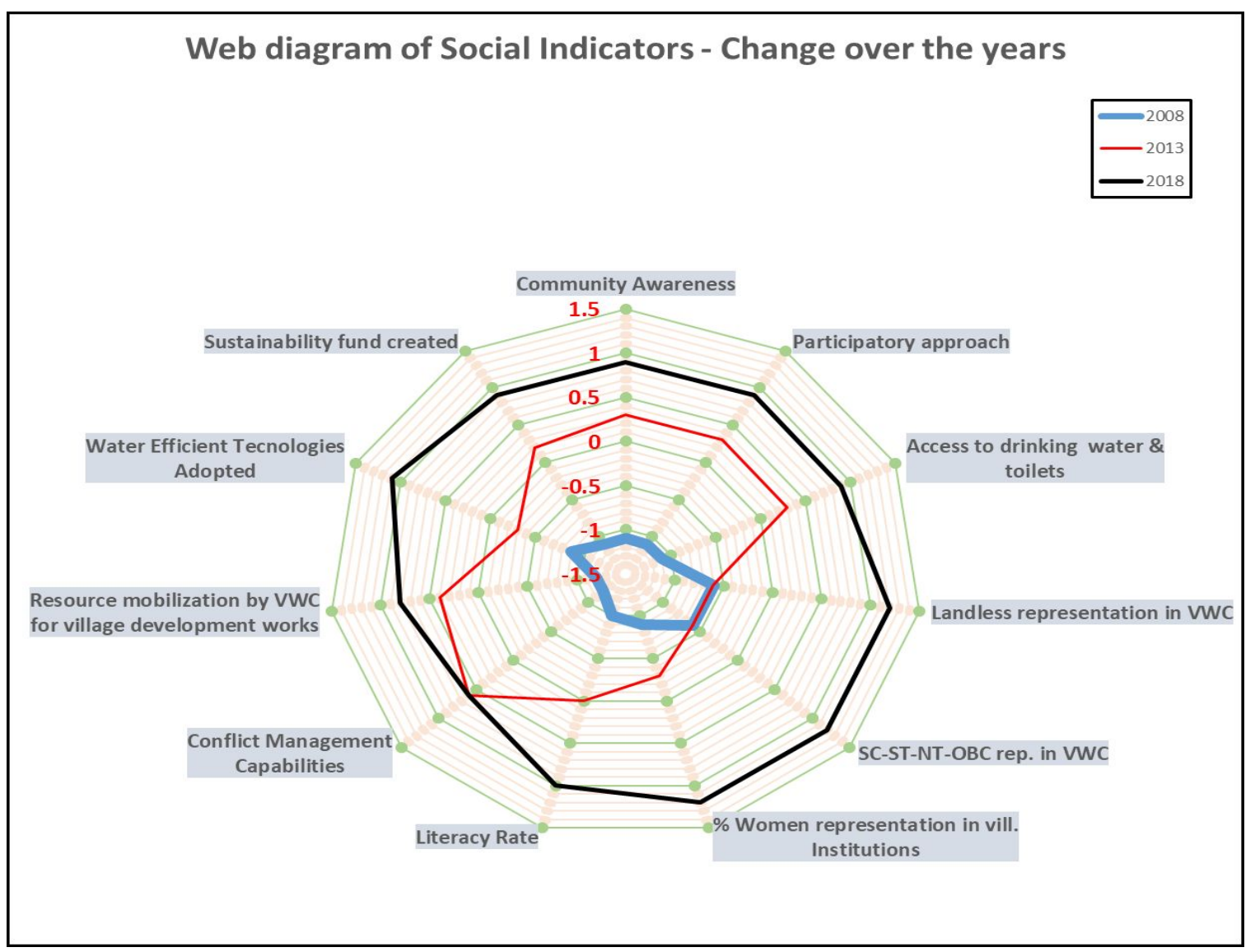

Figure 5. Web-diagram of social sustainability across three periods (2008, 2013 and 2018)

The web diagram of social indicators indicate consistent improvement over the years. Out of 11 indicators, nine indicators have shown positive change from 2008 to 2013. Especially, the community participation, awareness and conflict management have been the maximum on the scale of web diagram. "People have understood the importance of water and are working harder to uplift their economic status due to increased water availability, so are willing to actively participate in maintenace too"-VWC Member. As per Ms. Prajakta, Ex. Sarpanch (Gram-Panchayat Head), "Gram-Panchayat has an inclusive approach towards the community and offers the Govt. schemes such as housing scheme, toilet construction etc." In addition to project funds, the funds mobilized by VWC and Gram Panchayat during the project period itself was Indian Rs (INR) 8192 478/- and post project period till 2018 was INR 10252 878/-.

About $61.42 \%$ households have received the direct benefits and due to overall increase in water regime in the aquifer, most of them have now the access to irrigation water.All the households have year-round drinking water availability now and all have the access to toilets (66.4\% households in 2008, 80\% in 2013 and $100 \%$ in 2018).

It is evident that socially backward communities and landless households were initially excluded from the VWC. During the process of this study and specific interactions on these aspects with community, VWC was reconstituted and hence appears to be more inclusive in 2018. Women representation in different village level institutions was changed marginally during and after project. This shows enhancement in gender sensitivity among the community. In response to the impact on downstream area of Randullabad, a positive impact is evident from the increased water availability in the wells surrounding the stream in the village Karanjkhop. Initially, a stretch of 3 to 4 kilometre, i.e. upto another village Sonke (further downstream) used to benefit due to the augmentation of ground water in the aquifer. As per community leader Mr. Ganpat Jagtap, "During last 3 to 4 years, the drinking water supply well of downstream village -Karanjkhop has been also augmented."

More than 25-30 progressive community leaders have been emerged, these leaders are part of the various social committees and Gram-Panchayat. They participate in the various discussions, seek suggestions from village elders and then collectively take decisions at a Gram Sabha (Note 3) 
Another important aspect to be noted is the conflict management ability of community institutions, especially VWC and Grampanchayat. The conflict management ability of institutions was developed during the project period itself. Which seems to have played important role in bringing in the substantial amount of resources through convergence and also mobilise farmers to be part of the development process.

\section{Role of Support Organizations}

This project had a special arrangement of implementation through Gram Panchayat (GP) and not through NGO or Government organization as usually practiced elsewhere. The GP as Project Implementation Agency (PIA) proved to be successful. Project was implemented by the GP of Randullabad village through Village Watershed Committee and with the facilitation of BAIF Development Research Foundation, Pune as a RSO (Resource Support Organization). In addition to the financial support, National Bank for Agriculture and Rural Development (NABARD) also was responsible for overall monitoring in addition to RSO. The weather monitoring system was established through ACWADAM, an organization having competence in hydrogeology, which also provided support to project in ground water management. The combination of GP as PIA, BAIF as RSO has worked well. Implementing organisations and Gram-Panchayat certainly played an important role in both successful implementation of the project as well as its sustainability.

\section{Incentives for common pool resource management}

The major incentive is "water for all". Due to efficient water management, village has gone tanker-free, all are getting round the year water supply. Due to ground water sharing through group wells almost all the farmers have access to water for irrigation, except few farmers who have permanently migrated and not cultivating their lands. It is the direct incentive for maintenance of the watershed development measures. There are only about 10 new wells constructed after 2013, and other existing 167 wells were just deepened and lined.

The distribution of wells in any typical watershed is usually very sparse in upper reaches and highly concentrated in lower reaches. Randullabad is exception to this generic situation. The map in figure 6, shows the even distribution of the irrigation wells. Hence all the farmers in upper, middle and lower reaches have access to water. Such distribution of ground water is possible due to the access of water only though dug-wells taping only shallow aquifer. Wells across watershed provide water for irrigation to all land holders. This is a major motivating factor for entire village to take care of the soil and water conservation measures.

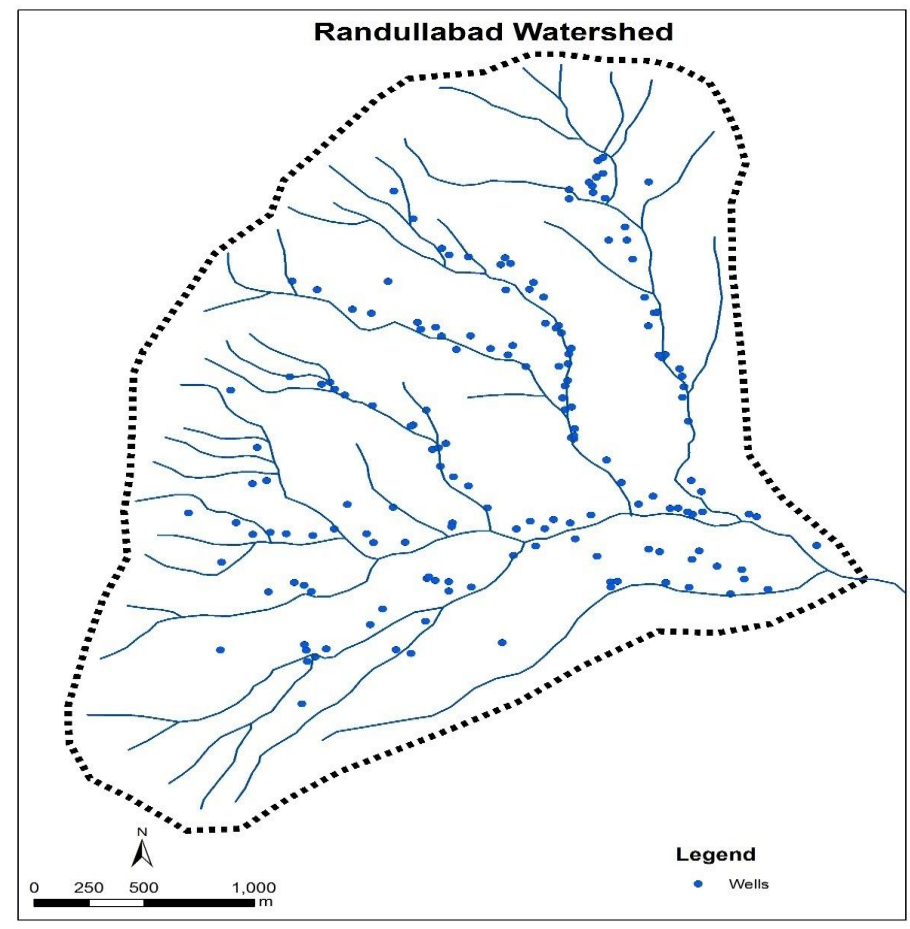

Figure 6. Spread of open wells in Randullabad Watershed 


\section{Management of private and common lands}

The private farm lands were treated with bunding. Most of the private wasteland has been brought under cultivation and hence managed better. Village doesn't have any common land, however, the entire upper reach has a hilly terrain owned by forest department. Through Joint Forest Management Committee (JFMC), the forest owned land has been treated through Continuous Contour Trenches (CCT) and tree plantation as per the schedule of forest dept. Community has agreed for its protection banning tree felling and free grazing. This has also resulted in increased vegetation cover.

\section{Externalities}

Like any other village in India, Randullabad also gets affected due to political processes, especially during the elections of Panchayati Raj Institutions. People get aligned to different political parties, the thoughts get divided and the risk of dis-integration goes up. However, it has been observed that the villagers were able to get back to normalcy within a period of couple of months after elections. In the routine development process, there appears to be no outside effect. Rather, the level of convergence of funding shows that there has been a major support from all sides to the village.

Market has played a positive impact on the economy of the village, as there appears to be shift towards vegetable cultivation and other cash crops.

\section{ANOVA (Analysis of Variance)}

The inference of comparison of parameter change between years 2008-2013-2018 as per ANOVA (Analysis of Variance) for Social Sustainability Parameters provided in Appendix B, Table B1, substantiates the interpretations as mentioned above as all parameters are significantly different at $\alpha=0.05$ level.

Appendix B, Table B2 gives the comparison of social sustainability parameters across three different years i.e. the year of start of project 2008, the year of project completion 2013 and the year of study 2018. The inference of this analysis is as follows: The change in community awareness between year 2008 and 2013 is highly significant at $\alpha$ $=0.05$ level. The change between 2008 and 2018 as well as between 2013 and 2018 is also highly significant. Similarly, the change in other parameters viz., Participatory approach, Access to drinking water \& toilets, Women representation, literacy rate, Resource mobilization, Water Efficient Technologies Adopted and Sustainability fund created, between the years 2008 and 2013, 2008 and 2018 and between 2013 and 2018 is highly significant.

The change in the parameters - 'representation of landless in VWC' and 'representation of SC, ST, NT, OBC in VWC' between the year 2008 and 2013 were not significant at $\alpha=0.05$ level, but the change between 2008 and 2018 and between 2013 and 2018 is highly significant. In case of parameter 'Conflict Management Capabilities of VWC', the change between the year 2008 and 2013 and between 2008 and 2018 is highly significant but there is no change between year 2013 and 2018.

Overall, the strength of all social parameters has been increased to maximum extent in 2018, i.e. during five years after project completion, hence the watershed appears to be strong in terms of social sustainability.

\subsection{Economic Sustainability}

As per the sustainability framework by Kakade 2017, economic sustainability indicators are measured in terms of Family income, Distribution of benefits, Migration, Human induced capital or assets, Farm production and diversification,Access to credit and Access to market. All these indicators have been measured and quantified data has been analyzed, except the indicator access to market. Hence this couldn't be considered for comparative analysis in web-diagram, but is explained separately.

In the similar way as done for social indicators, the values of economic indicators used for the economic sustainability analysis have been converted into a standardized values on a common scale as shown in the Table 5 . 
Table 5. Standardized values of economic indicators

\begin{tabular}{|c|c|c|c|c|c|c|c|c|}
\hline$\stackrel{\vec{\Xi}}{\grave{\Xi}}$ & 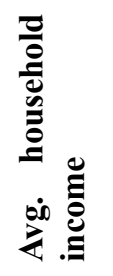 & 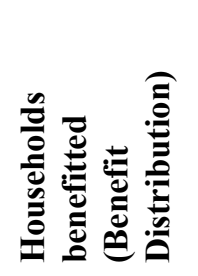 & 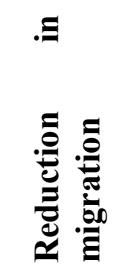 & 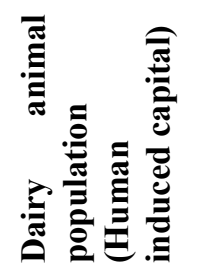 & 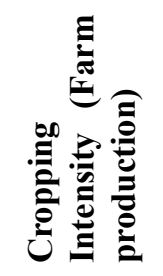 & 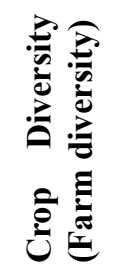 & 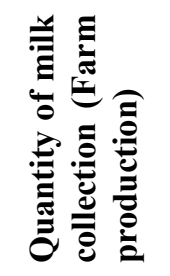 & 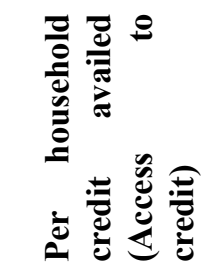 \\
\hline 2008 & -1 & -0.8 & -0.9 & -1.2 & -1.2 & -1.2 & -1 & -1 \\
\hline 2013 & 0 & -0.5 & -0.3 & 0.4 & 0.4 & 0.6 & -0.1 & 0 \\
\hline 2018 & 1 & 1.2 & 1.2 & 0.8 & 0.8 & 0.6 & 1.1 & 1 \\
\hline
\end{tabular}

The web diagram constructed on the basis of the standardized values of the indicators at the year 2008, at 2013 and in the year 2018 is as given in figure 7.

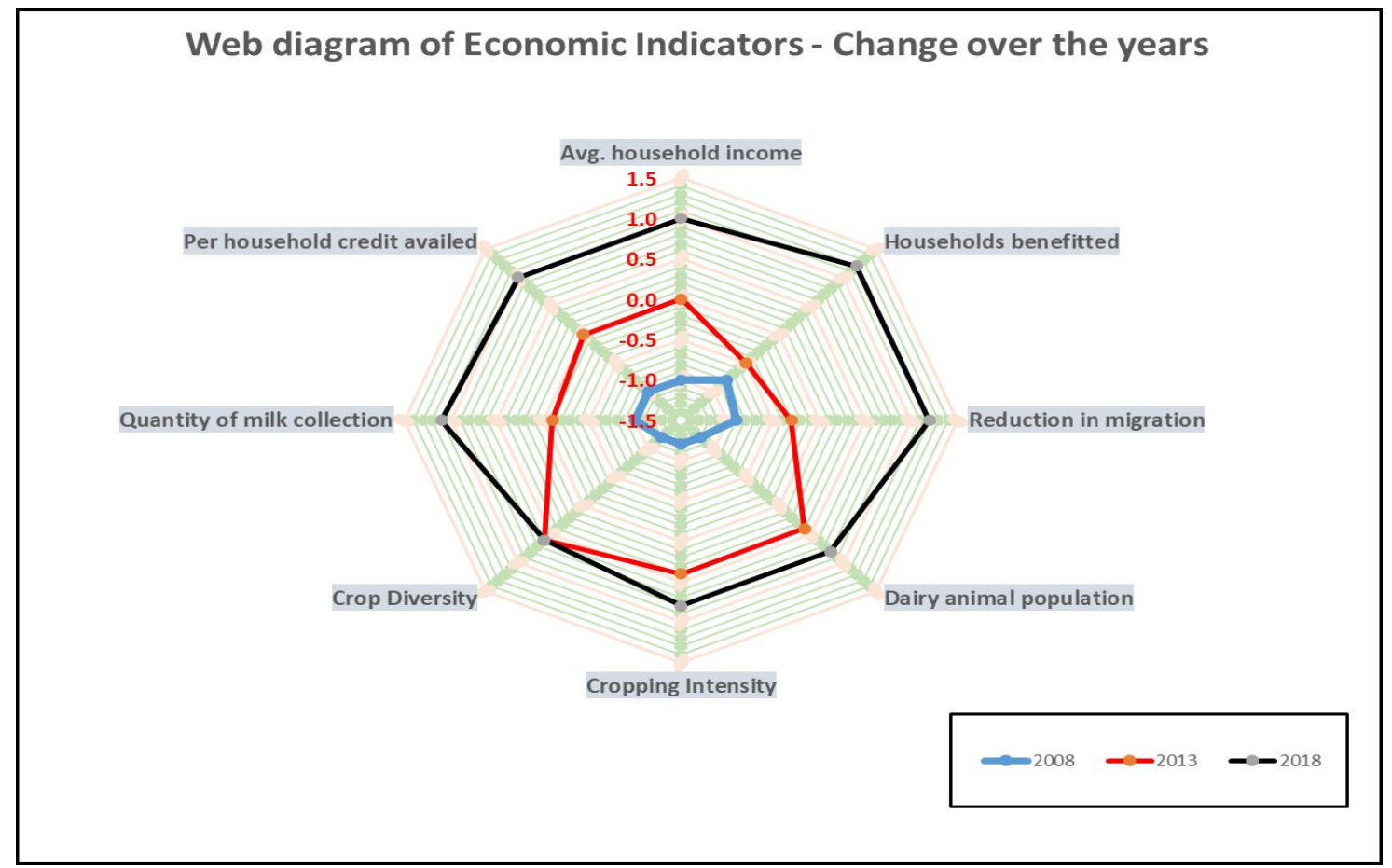

Figure 7. Web-diagram of economic sustainability across three periods

The web diagram indicates the continuous improvement in all parameters over the year 2008. But, the change has been not uniform as the reach of benefit and reduction in migration is not upto the level of the achievements in case of other indicators. However, both of these indicators have achieved the maximum levels in 2018. This can be attributed to enhanced capabilities of local institutions during the project resulting in mobilizing the resources for additional activities leading to benefits. (Refer web diagram of social sustainability). Three key indicators measuring the agriculture production and livestock, viz. cropping intensity, crop diversity and dairy animal production have achieved higher results within project period itself. The cropping intensity had gone up from $124.79 \%$ in 2008 to $160.25 \%$ in 2013 . It was slightly increased further to $168.19 \%$ in $2017-18$. Increase in dairy animals as well as replacement of local cows with cross-bred cows has reflected positively on the milk production. The daily milk collection at dairy centers had been increased from 600 litre in 2008 to 1205 litre in 2013 to 1930 litre in 2018. There is also a significant increase in high value assets from the year 2008 to 2018; Tractors from 2 to18, Tempo/ Pick-ups from 2 to 10, Trucks from nil to 8, Buses from nil to 5, Jeep/Six Seat Transport from nil to 5 and Cars from nil 37.

The average increase in income from 2008 (Rs. 97 431/household) to 2017 (Rs 175 174/household) was Rs 77743 /household and about the same level of increase was observed among the open category group. The major rise was 
among the tribal group of two households (Rs $252000 / \mathrm{hh}$ ). So this is quite significant jump in income of these two households. It is observed that in 2008, primary source of landless households was service (employment outside watershed) and secondary source was agriculture labour. In 2017, it was shifted to business as primary source and service as secondary. There was reduction in the income from agri-labour indicating that the dependency of landless on agriculture labour had gone down. A shift from service as a major income source to agriculture has been observed.

In Randullabad, there was major reduction in number of people going out for employment from 133 people in 2008 to 54 in 2018. Out of 54 people, only 3 had gone out for unskilled work and others either as skilled workers or as professional employees or for higher education. Previously, during the non-farming season, landless farmers used to work in the farms of the neighboring villages or migrate to the cities and work on the menial jobs. But in the last five years, their migration has reduced. They now get a sufficient amount of work or employment in the village. Thus, the distress migration has been almost negligible. In the group discussion held on 10.12.18, Mr. Nandkumar Deshmukh (a farmer) said, "Additional livelihood opportunities for farm labourers are generated for surrounding villages too due to production of additional crops. Randullabad village provides additional wage employment to more than 150 farm workers every day during August to November, which is a harvesting season. Majority of these farm labourers are women as most of the men work in nearby factories."

A sharp increase in uptake of loans from INR 16227 per household in 2008 to INR 56232 in 2018 has been observed. As it is observed in the changes in cropping intensity, crop diversity and sources of income, the agriculture and allied sectors have been flourished in the watershed during and post watershed project period. In addition to water availability, contribution of credit must have been a contributing factor for fast economic growth. The market channels for cash crops such as potato, pomegranate and that for milk have been well established.

In the year 2018, the values of indicators which were weak to medium have increased to the levels of indicators with higher values. This indicates a continuous economic growth of watershed community along with spread of benefits to most of the households. Rise and diversity in income also shows the livelihood risk minimization. Development appears to be balanced and inclusive. Thus from the web diagram, watershed appears to be strong in terms of economic sustainability.

\section{ANOVA (Analysis of Variance)}

The Appendix B, Table B3 and Table B4- Analysis of Variance and Comparison of parameter change between years 2008-2013-2018 respectively endorse that the changes in all the indicators are significant compared to baseline. ANOVA for Economic Sustainability Parameters show that all parameters are significantly different at $\alpha$ $=0.05$ level.

Inference of Appendix B, Table B4 of comparison of economic parameter change across three different years i.e. the year of start of project 2008, the year of project completion 2013 and the year of study 2018 shows that the change in all the parameters except 'crop diversity' between year 2008 and 2013 is highly significant at $\alpha=0.05$ level. The change between 2008 and 2018 as wells as between 2013 and 2018 is also highly significant. The change in the parameter 'crop diversity (numbers of crops grown)' between the year 2008 and 2013 and between 2008 and 2018 is highly significant at $\alpha=0.05$ level. However, the numbers of crops grown between 2013 and 2018 did not change significantly.

\subsection{Ecological Sustainability}

It is evident from the worldwide studies and agreements that sustainable development is possible only if the resources are protected, used judiciously without depletion and enough stocks are maintained for future generations. The main resources in case of any watershed in general and Randullabad in particular include soil, water and vegetation. The status of these resources has been assessed in the study. The measurements of indicators include Soil conservation by Private wasteland brought under cultivation, Siltation in water reservoirs by Checkdams in good condition, Water - quantity and quality, Water storage capacity and Area irrigated in Rabi, Water use efficiency by Area under water efficient technologies, Ground water status by Avg. static water level in wells and Forestry and stream bank vegetation by Area under vegetative cover. Biodiversity assessment was done only once in 2011, it couldn't be considered for comparative analysis.

The values of ecological indicators used for the ecological sustainability analysis were converted into a standardized values on a common scale as shown in the Table 6 . The standardization has been done in the similar way as it is done for social and economic indicators. 
Table 6. Weights of ecological indicators

\begin{tabular}{|c|c|c|c|c|c|c|c|}
\hline$\stackrel{\grave{\Xi}}{\grave{\nu}}$ & 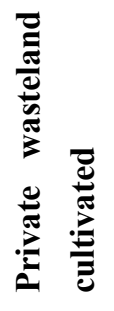 & 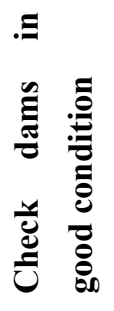 & 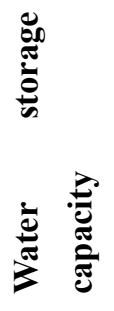 & 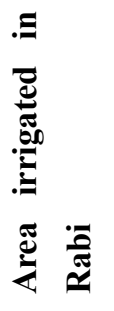 & 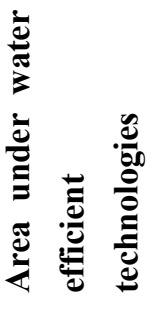 & 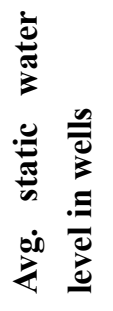 & 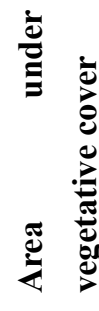 \\
\hline 2008 & -1.2 & -0.1 & -0.6 & -1.2 & -0.9 & -1.2 & -0.9 \\
\hline 2013 & 0.6 & -1 & -0.6 & 0.3 & -0.3 & 0.6 & -0.3 \\
\hline 2018 & 0.7 & 1.1 & 1.2 & 0.9 & 1.1 & 0.7 & 1.1 \\
\hline
\end{tabular}

The web diagram constructed on the basis of the standardized values of the indicators at the year 2008, at the year 2013 and in the year 2018 is as given in figure 8 .

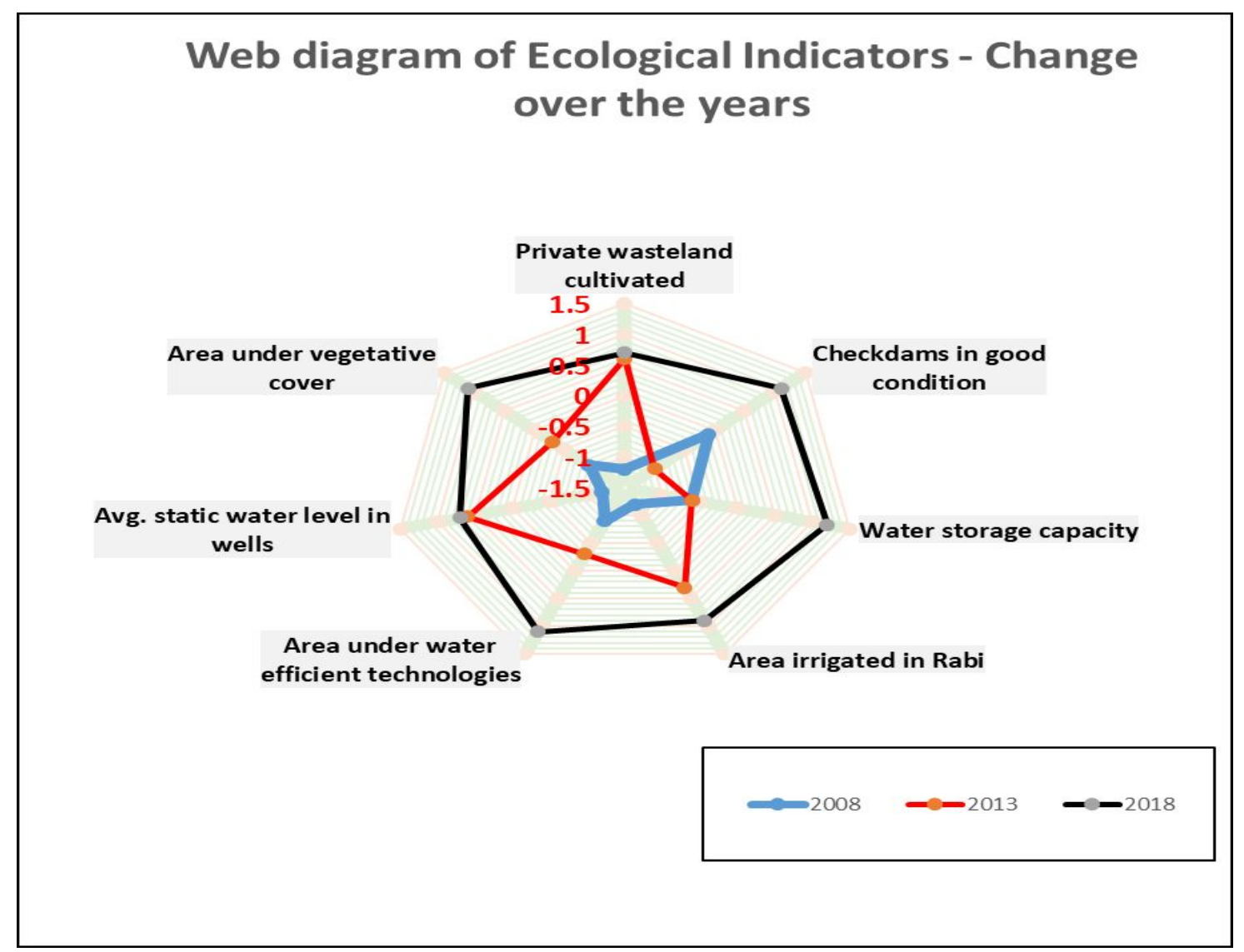

Figure 8 . Web-diagram of ecological sustainability across three periods

The web-diagram of ecological sustainability in figure 8 indicate how the 2018 web-line is stretched towards maximum level of sustainability. The lacunae during the project duration have been addressed and hence all the indicators show substantial improvements in the year 2018 over both base level of 2008 and 2013. During the net-planning exercise, about 740 ha land was found to be susceptible to soil erosion. Of this 732 ha was treated through different soil conservation measures such as farm bunding in cultivated area, continuous contour trenches in forest area and other drainage line protection and water conservation structures in the drainages.

Regarding the condition of checkdams, there appears to be deterioration of quality in 2013 against 2008.. In the year 2018, three checkdams required repair out of 18 constructed before 2009, two required repair out of 8 structures constructed during 2009 to 2013 and only one structure required repair out of 17 structures constructed 
after 2013. This also means the quality of structures constructed after project period was substantially improved, which may be due to improved capacity of VWC and Grampanchayat. The improved capacity of these institutions is also reflected in the continuous increase in vegetation cover, both in forest land as well as the riparian vegetation.

Water storage capacity created appears to be marginally increased during project, as the 8 checkdams constructed in the drainage line had limited storage capacities. The water storage capacity of water harvesting structures was marginally increased from 512.37 TCUM (Thousand Cubic Meter) in 2008 to 512.17 TCUM in 2013 till the project end. While it was substantially increased to 1158 Thousand CUM after 2013. The major capacity enhancement is due to 16 new earthen dams and farm ponds constructed after the project through convergence.

Another observation is about the improvement in static water levels in the aquifer during the project period and almost the same levels have been maintained after project period. There have been several initiatives including ban on bore wells to manage the water resources and restrict over-exploitation of ground water. Area under irrigation through micro irrigation has been increased from zero in 2008 to 49 ha in 2018. The result of these efforts is seen in the ground water status of village. Since the beginning of project, Randullabad has a system of measuring the depth of water in the selected monitoring wells. Out of total 167 wells 29 wells were selected for monitoring water levels. Monthly readings were taken of all the 29 wells. Figure 9 below shows that despite the uneven annual rainfall pattern since 2010 till 2017, the average ground water table has been stable.

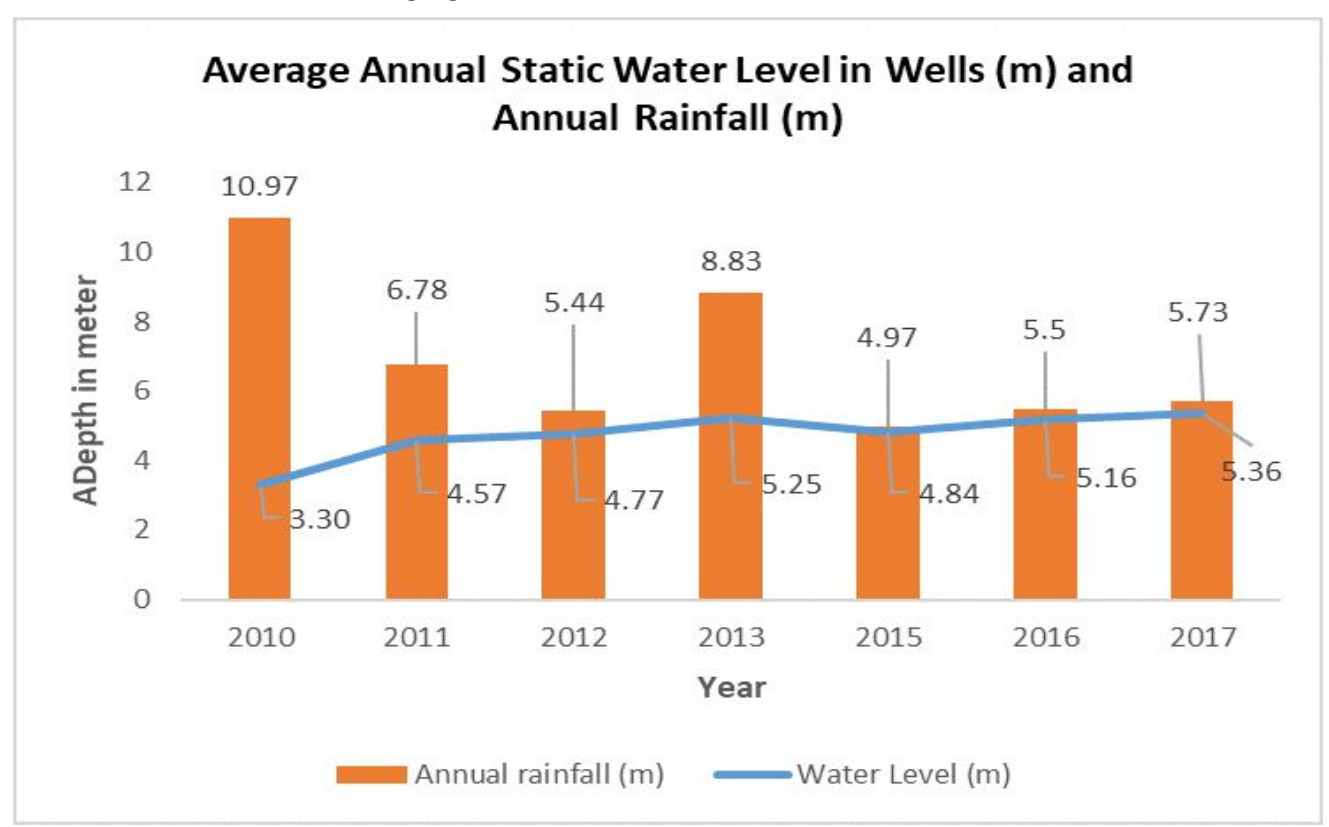

Figure 9. Average annual static water level in wells (m) and annual rainfall (m)

This indicates the good governance of village institutions of the water resources, despite the fact that the area under the irrigation has been continuously increasing. Major jump in irrigated area is seen in kharif and rabi season in 2013 compared to 2008. It is clear that change from 11 ha (kharif) in 2008 to 89.36 ha in 2013 and from 47 ha (rabi) in 2008 to 164.5 ha in 2013 is due to watershed development project and good water governance. There is also substantial increase in irrigated area in kharif (201.1 ha) of 2017 against 2013 (89.36 ha). There is direct correlation between the two indicators - 'increased ground water table (water level in the wells)' and major addition in the 'water storage capacity' in the watershed with 'increase in area under irrigation'.

Vegetation cover found out using geomatics is found to be $1.03 \mathrm{sqkm}$ in $2008,1.55 \mathrm{sqkm}$ in 2013 and $2.62 \mathrm{sqkm}$ in 2018. The major increase was observed in the forest area, while there has been some change in riparian vegetation. There were 27 trees, 5 grasses, 11 bird species, 9 reptiles, 13 mammal species and some invertebrates like earthworms, crabs, insects, cited and identified by the villagers (Trupti, 2011).

The ecosystem of the watershed appears to be continuously improving, despite the fact that there has been substantial economic growth over last ten years.

\section{The ANOVA - Analysis of Variables}

The ANOVA and the changes in the values of indicators between the years 2008, 2013 and 2018 as shown in the Appendix B, Table B5 and Table B6 show the significant difference in the year 2018 over the baseline and also 
over 2013. The ANOVA shows that the change in all the parameters between year 2008 and 2013 is highly significant at $\alpha=0.05$ level. Similarly the change between the year 2008 and 2018 as well as between 2013 and 2018 is also highly significant. This reveals that the watershed project has achieved the balanced development.

\section{Discussions}

From the study observations, it is evident that Randullabad has made all-round development. The resources have been developed using project and through several other sources. The institutions have been empowered, they have shown their ability leading the development process of village in a close coordination with Gram Panchayat, and other organisations. The continuous economic growth, resource growth and enrichment of ecosystem are the signs of sustainability.

\section{Web diagram for overall sustainability}

The actual values were standardized with a mean of 0 and 1 standard deviation. Parameters under Social, Economic and Ecological aspects were grouped and the simple averages of standardized values in different years (i.e. the sustainability figures were derived by averaging the standardized values under each of the social, economic and ecological parameters) were used to build the web diagram.

The Sustainability values were derived by averaging the standardized values under each of the social, economic and ecological parameters.

The web diagram(Figure 10) shows very strong level of sustainability in all three domains social, economic and ecological parameters in the year 2018. Watershed was very weak in terms of sustainability in 2008 . The values in the year 2013 appear to have achieved medium level of sustainability in all three domains. It is evident that the economic growth is not exploitative, as despite the substantial economic growth over baseline, the ecological parameters have been also improved. The improvement in natural resource base, judicious use of the resources and good governance has ensured non-exploitative economic growth.

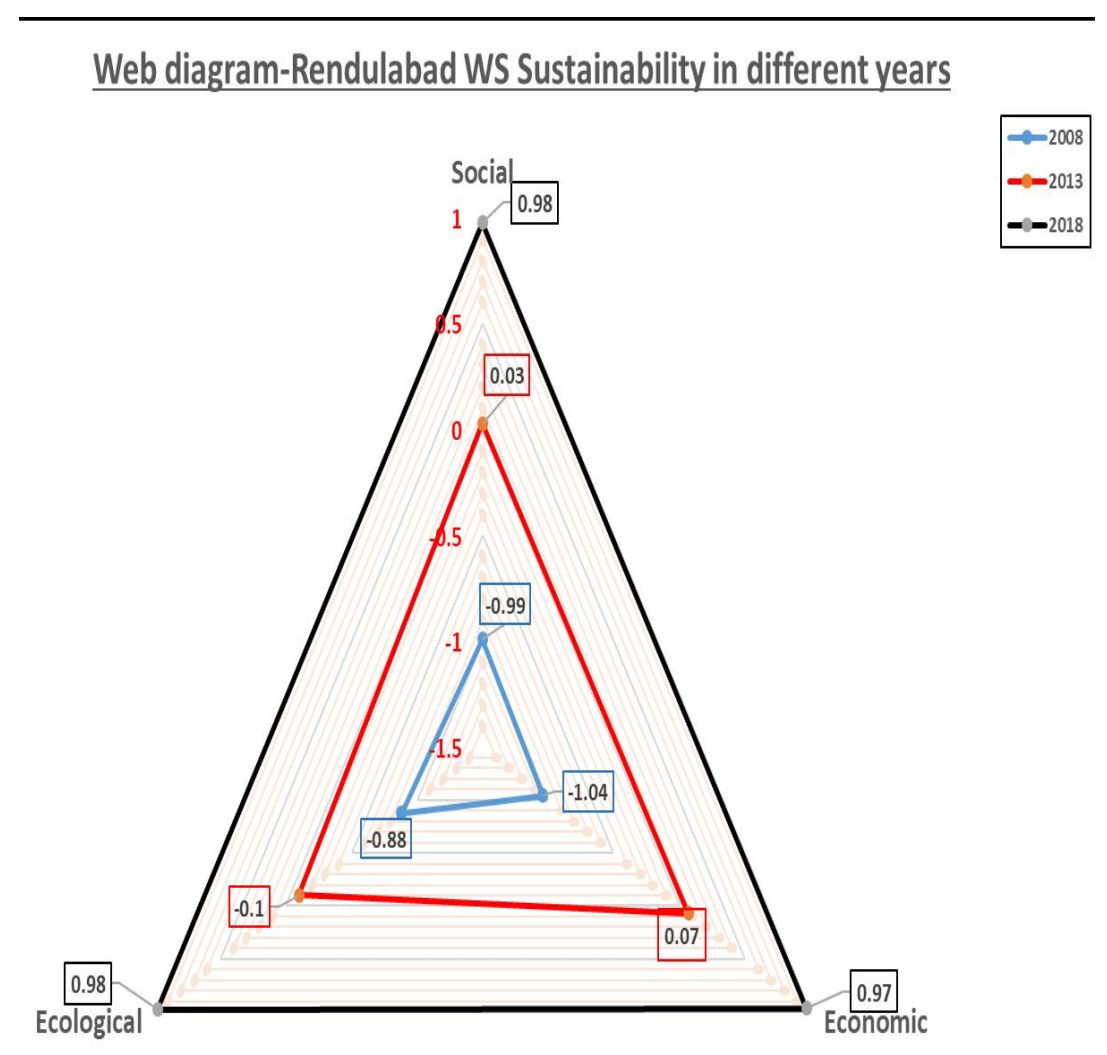

Figure 10. Web diagram of Randullabad Watershed Sustainability in different years $(2008,2013$ and 2018)

Thus Randullabad watershed appears to have achieved highest level of sustainability scores in all three domains in 2018. This looks like an ideal situation, one may expect. This can be attributed to following major reasons - (a) The social domain is very strong. Participatory processes in project implementation and post-project management, 
good governance systems through institutions, (b) Active and joint role played by both VWC and Grampanchayat, Proactive and inclusive governance by these institutions for resource management and utilization (c) The resources mobilized by the village institutions after project completion. This has helped saturate the conservation measures in watershed. (d) Although it was a typical watershed development project under a structured programme of IGWDP, project design was not restricted to only the expected interventions under project. In addition to resource conservation, there has been equal focus on farm productivity, efficient use of land and water resources, market oriented production system and quality of life measures such as health check-ups, water supply and sanitation. Thus the project design was very comprehensive. A reputed organisation, BAIF was in the role of facilitation to implement the project. VWC and Grampanchayat continued good contact with BAIF in seeking the guidance for continuous development.

The sustainability study of Randullabad with a data of pre-watershed project, at the completion and five year post-completion of project was undertaken using the new sustainability assessment framework. The study could be successfully conducted using the new framework and in addition, a refinement of few indicators in the framework was also possible. Together with the study of 36 IGWDP watersheds after 12 to 15 years of its completion, Randullabad study has provided a base for new comprehensive framework and methodology for sustainability assessment of the watershed projects in India

\section{Conclusions}

The major contribution of the study is in terms of validation of a new framework and methodology by Kakade, 2017 for sustainability assessment of watersheds. This methodology will be useful in designing the sustainable-watershed projects, natural resource conservation projects or river basin management projects and mainly the framework will be useful for Sustainability assessment of micro-watershed to macro-watershed level projects. The indicators adopted for assessment found to be useful in the sustainability assessment and were useful in identifying the gaps in sustainability of some areas, which could be brought to the notice of community institutions. The local leadership and institutions could understand the areas of improvement and acted immediately to address those. Hence performance some of the indicators especially related to equity could be improved during the study. A final new study framework is provided in the following chart in figure 11.

In the process of validation of the framework, it was revealed that in addition to the indicators of sustainability assessment adopted from Kakade 2017, the indicators which also have very important role in higher impacts and sustainability include following:

1) Project Design

2) Key stakeholders

3) Project objectives

4) Project activities

5) Sources of funding

6) Implementation methodology

These additional indicators or the parameters are added in the middle (triangle) of the framework considering the importance of the design, funding and implementation of project.

\section{Sustainability status of Randullabad watershed}

Randullabad watershed has scored maximum in all fronts on a scale of 0 to 1 in web-diagram. In social domain, the scores have been raised from -0.99 in 2008 to +0.03 in 2013 and finally to +0.98 in 2018. In case of ecological domain, the scores were -0.98 in $2008,-0.1$ in 2013 and was raised to a level of +0.98 in 2018 . The economic growth has been also very high, which was increased from -1.04 in 2008 to +0.07 in 2013 and to the level of +0.97 in 2018. Thus the Randullabad watershed is found to have achieved high level of sustainability.

The key contributing factors include the role of capable local institutions in project management and governance, comprehensive project design and facilitation of a reputed external organization - BAIF. 


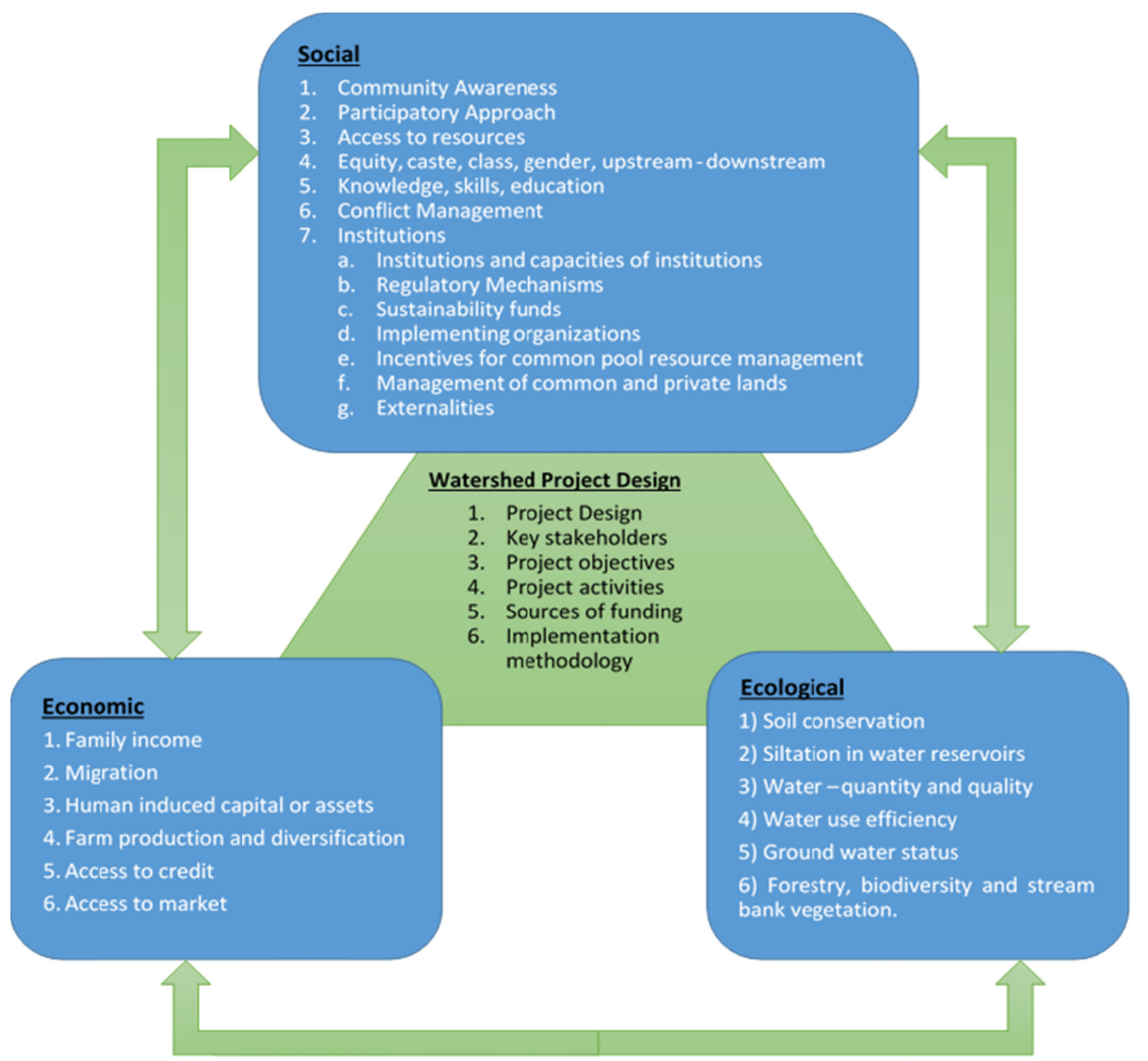

Figure 11. Sustainability assessment framework

\section{Acknowledgments}

This paper is an outcome of the $\mathrm{PhD}$ research of the first author at 'Centre for Technology Alternatives for Rural Areas' (CTARA), IIT Bombay, with the guidance of Prof. N.C. Narayanan and co-guide Mr G.G. Sohani. The project was implemented by Gram Panchayat of Randullabad village through "Jai Hanuman Panlot Vikas Samiti" - Village Watershed Committee. BAIF Development Research Foundation, Pune facilitated the Grampanchayat and VWC in project implementation and the project was financed by 'National Bank for Agriculture and Rural Development' (NABARD) - Regional Office, Maharashtra, India, under Indo-German Watershed Development Project.

\section{References}

Brundtland Gro Harlem. (1987). Our Common Future - From One Earth to One World. World Commission on Environment and Development. United Nations, Oxford University Press.

Chaturvedi, V. (2005). Maintenance of Physical Assets in Watershed. Research Report on Watershed Development. Development Support Centre (DSC), Ahmedabad.

Ciegis Remigijus, Ramanauskiene Jolita, Martinkus Bronislovas. (2009). The Concept of Sustainable Development and its Use for Sustainability Scenarios. The Economic Conditions of Enterprise Functioning. Inzinreine Ekonomika- Engineering Economics, (2). 
Joshi, P. K., Jha, A. K., Wani, S. P., Laxmi, \& Shiyani, R. L. (2005). Meta-analysis to assess impact of watershed program and people's participation. Comprehensive Assessment Research Report 8. Colombo, Sri Lanka: Comprehensive Assessment Secretariat.

Kakade, B. K. (2017). Sustainability Assessment of Watershed Development Programme in India. Thesis (draft) submitted in partial fulfilment for the Degree of $\mathrm{PhD}$. Center for Technology Alternatives for Rural Areas (CTARA) Indian Institute of Technology, Bombay.

Keremane Ganesh, B., McKay, J., \& Narayanamoorthy, A. (2006). The Decline of Innovative Local Self-Governance Institutions for Water Management: The Case of Pani Panchayats. International Journal of Rural Management, 2(1), 120-121. https://doi.org/10.1177/097300520500200106

Lata, A. S., \& Samra, J. S. (2001). Revisiting Watershed Management Institutions in Haryana Shivaliks, India. Central Soil and Water Conservation Research and Training Institute, Chandigarh.

Lobo, C. (1996). Institutional Arrangements and Impact of Participatory Natural Resource Management. WOTR, Ahmednagar.

Reddy, C. B., \& Ravindra, A. (2004). Watershed Development Programme: Understanding Investments and Impacts. Report of the Study of the Impact of Five Watersheds in Andhra Pradesh; WASSAN, Hyderabad.

Satpute Trupti. (2011). Introduction of Ecological Restoration Measures in Randullabad Watershed. A Report submitted for the Partial Fulfillment of The Spark Fellowship Programme. BAIF Development Research Foundation, Warje, Pune.

Sharda, V. N., Samra, J. S., \& Dogra, P. (2005). Participatory watershed management programmes for sustainable development: Experiences from IWDP. Indian J. of Soil Conserv., 33(2), 93-103.

Sharma. (2005). Chapter 3 A new approach to watershed management. Retrieved from http://www.fao.org/docrep/ pdf/009/a0644e10.pdf

Subha, V., Hubert, S. H. G., \& Pieter, V. D. Z. (2005). A Conceptual Framework for Sustainable Watershed Management. ICID 21st European Regional Conference 2005-15-19 May 2005- Frankfurt (Oder) and Slubice- Germany and Poland.

\section{Notes}

Note 1. Gram Panchayat is a village level democratic body - elected by the citizens in the village

Note 2. BAIF Development Research Foundation is a Non-Government Organization based in Pune, India

Note 3. Gram Sabha-Body of all the adults in the Gram-Panchayat

\section{Appendix A}

Details of Project activities and expenditure

\begin{tabular}{|l|l|l|l|l|}
\hline \multicolumn{5}{|c|}{ Wndo German Watershed Development Project- FC III } \\
\hline \multicolumn{5}{|c|}{ Details of project activities and the expenditure } \\
\hline \multicolumn{1}{|c|}{ Project Activity } & Unit & $\begin{array}{l}\text { Number of } \\
\text { Units }\end{array}$ & $\begin{array}{l}\text { Project Expenditure } \\
\text { (Indian RS) }\end{array}$ \\
\hline Sr. No. & \multicolumn{1}{|c|}{ - Randullabad, Taluka -Koregaon, District-Satara } \\
\hline A. & Area Treatments & & & \\
\hline $\mathbf{1}$ & $\begin{array}{l}\text { Afforestation (AF)-Private land and Forest } \\
\text { land }\end{array}$ & & $\mathbf{2 2 2 . 8}$ & \\
\hline & Continuous Contour Trench & Cubic Metre & 11809.80 & 572894.00 \\
\hline & Refilling of Contour Trench & Running Metre & 32805.00 & 72307.00 \\
\hline & Plantation & Numbers & 5778.00 & 62023.00 \\
\hline & High Section Continuous Contour Trench & Cubic Metre & 6995.30 & 200267.00 \\
\hline & Gully Plug & Numbers & 4.00 & 3006.00 \\
\hline
\end{tabular}




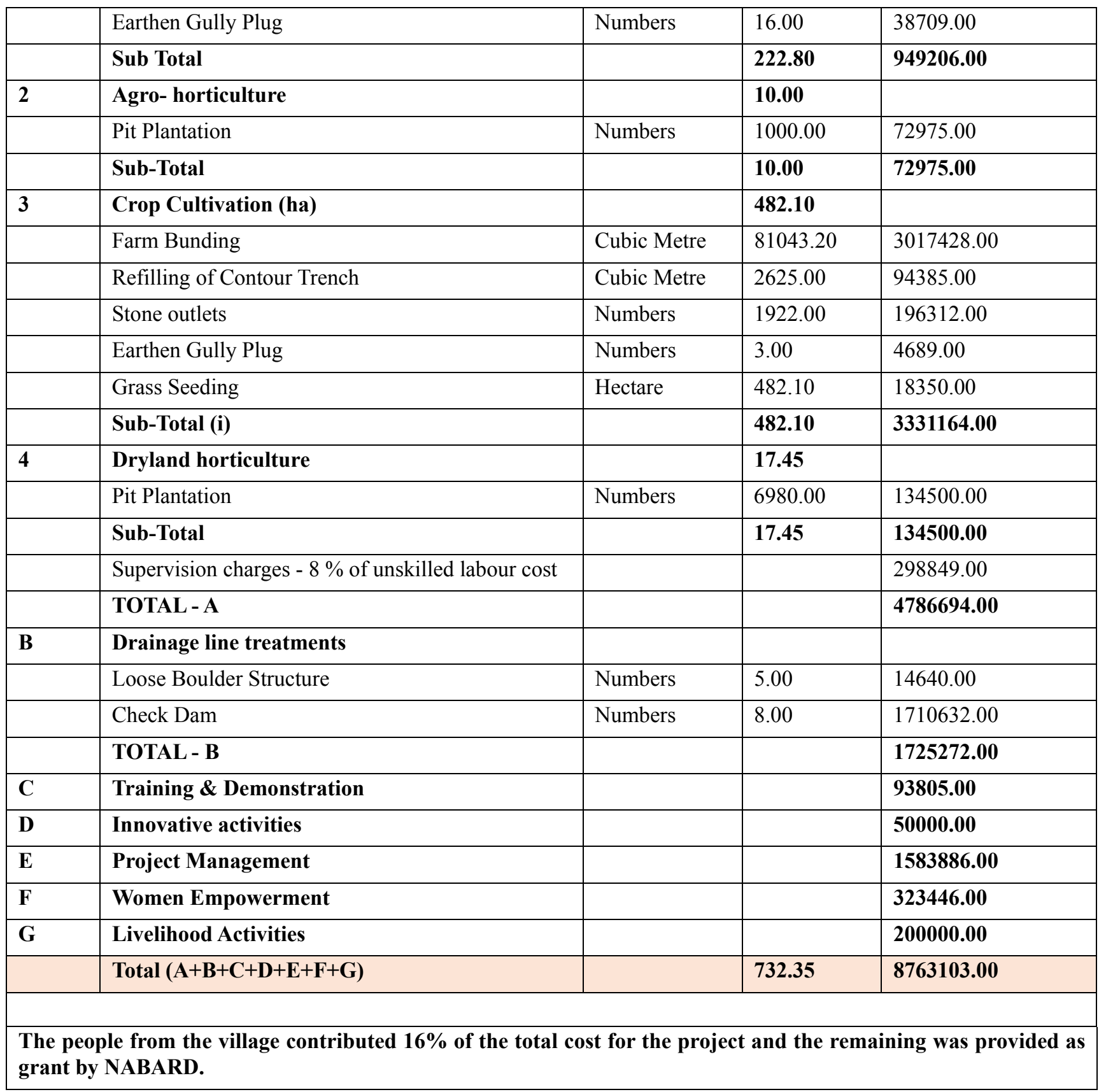

\section{Appendix B}

ANOVA (Analysis of Variance) for Social, Economic and Ecological Sustainability Parameters and Comparison of parameters change between years 2008-2013-2018

Table B1: ANOVA (Analysis of Variance) for Social Sustainability Parameters

\begin{tabular}{llllllll}
\hline & & $\begin{array}{l}\text { Sum } \\
\text { Squares }\end{array}$ & of & Df & $\begin{array}{l}\text { Mean } \\
\text { Square }\end{array}$ & F & \multicolumn{1}{c}{$\begin{array}{l}\text { Signific } \\
\text { ance }\end{array}$} \\
\hline $\begin{array}{l}\text { Community } \\
\text { Awareness }\end{array}$ & Between Groups & .093 & 2 & .047 & 20291884.109 & .000 \\
\cline { 2 - 8 } & Within Groups & .000 & 3 & .000 & & \\
\cline { 2 - 8 } & Total & .093 & 5 & & & .000 \\
\hline Participatory & Between Groups & .093 & 2 & .047 & 20291884.109 &. \\
\hline
\end{tabular}




\begin{tabular}{|c|c|c|c|c|c|c|}
\hline \multirow[t]{2}{*}{ approach } & Within Groups & .000 & 3 & .000 & & \\
\hline & Total & .093 & 5 & & & \\
\hline \multirow{3}{*}{$\begin{array}{l}\text { Access to drinking } \\
\text { water \& toilets }\end{array}$} & Between Groups & 887.409 & 2 & 443.704 & 11525542.157 & .000 \\
\hline & Within Groups & .000 & 3 & .000 & & \\
\hline & Total & 887.409 & 5 & & & \\
\hline \multirow{3}{*}{$\begin{array}{l}\text { Landless } \\
\text { representation in } \\
\text { VWC }\end{array}$} & Between Groups & .083 & 2 & .042 & 400040001.000 & .000 \\
\hline & Within Groups & .000 & 3 & .000 & & \\
\hline & Total & .083 & 5 & & & \\
\hline \multirow{3}{*}{$\begin{array}{l}\text { SC-ST-NT-OBC } \\
\text { rep. in VWC }\end{array}$} & Between Groups & 1.597 & 2 & .799 & 88414.949 & .000 \\
\hline & Within Groups & .000 & 3 & .000 & & \\
\hline & Total & 1.597 & 5 & & & \\
\hline \multirow{3}{*}{$\begin{array}{l}\text { \% Women } \\
\text { representation in } \\
\text { village } \\
\text { Institutions }\end{array}$} & Between Groups & 44.036 & 2 & 22.018 & 6723096.097 & .000 \\
\hline & Within Groups & .000 & 3 & .000 & & \\
\hline & Total & 44.036 & 5 & & & \\
\hline \multirow[t]{3}{*}{ Literacy Rate } & Between Groups & 16.002 & 2 & 8.001 & 181040.881 & .000 \\
\hline & Within Groups & .000 & 3 & .000 & & \\
\hline & Total & 16.002 & 5 & & & \\
\hline \multirow{3}{*}{$\begin{array}{l}\text { Conflict } \\
\text { Management } \\
\text { Capabilities }\end{array}$} & Between Groups & .053 & 2 & .027 & 9757073.195 & .000 \\
\hline & Within Groups & .000 & 3 & .000 & & \\
\hline & Total & .053 & 5 & & & \\
\hline \multirow{3}{*}{$\begin{array}{l}\text { Resource } \\
\text { mobilization } \\
\text { VWC }\end{array}$} & Between Groups & 11766.740 & 2 & 5883.370 & 204949425.884 & .000 \\
\hline & Within Groups & .000 & 3 & .000 & & \\
\hline & Total & 11766.740 & 5 & & & \\
\hline \multirow{3}{*}{$\begin{array}{l}\text { Water Efficient } \\
\text { Technologies } \\
\text { Adopted }\end{array}$} & Between Groups & 2476.248 & 2 & 1238.124 & 276161443.070 & .000 \\
\hline & Within Groups & .000 & 3 & .000 & & \\
\hline & Total & 2476.248 & 5 & & & \\
\hline \multirow{3}{*}{$\begin{array}{l}\text { Sustainability fund } \\
\text { created }\end{array}$} & Between Groups & 31.675 & 2 & 15.838 & 218646005.626 & .000 \\
\hline & Within Groups & .000 & 3 & .000 & & \\
\hline & Total & 31.675 & 5 & & & \\
\hline
\end{tabular}

Inference of above ANOVA: All parameters are significantly different at $\alpha=0.05$ level.

Table B2: Comparison of parameter change between years 2008-2013-2018.

\begin{tabular}{|c|c|c|c|c|c|c|c|}
\hline \multicolumn{8}{|c|}{ Multiple Comparisons } \\
\hline \multicolumn{8}{|c|}{ Least Significant Difference (LSD) } \\
\hline \multirow[t]{2}{*}{ Dependent Variable } & \multirow{2}{*}{$\begin{array}{l}\text { (I) } \\
\text { year }\end{array}$} & \multirow{2}{*}{$\begin{array}{l}(\mathrm{J}) \\
\text { year }\end{array}$} & \multirow{2}{*}{$\begin{array}{l}\text { Mean } \\
\text { Difference } \\
(\mathrm{I}-\mathrm{J})\end{array}$} & \multirow{2}{*}{$\begin{array}{l}\text { Std. } \\
\text { Error }\end{array}$} & \multirow[t]{2}{*}{ Sig. } & \multicolumn{2}{|c|}{ 95\% Confidence Interval } \\
\hline & & & & & & $\begin{array}{l}\text { Lower } \\
\text { Bound }\end{array}$ & Upper Bound \\
\hline \multirow{3}{*}{$\begin{array}{l}\text { Community } \\
\text { Awareness }\end{array}$} & \multirow[t]{2}{*}{2008} & 2013 & $-.20001^{*}$ & .00005 & .000 & -.2002 & -.1999 \\
\hline & & 2018 & $-.30002^{*}$ & .00005 & .000 & -.3002 & -.2999 \\
\hline & 2013 & 2008 & $.20001^{*}$ & .00005 & .000 & .1999 & .2002 \\
\hline
\end{tabular}




\begin{tabular}{|c|c|c|c|c|c|c|c|}
\hline & & 2018 & $-.10001^{*}$ & .00005 & .000 & -.1002 & -.0999 \\
\hline & 2018 & 2008 & $.30002^{*}$ & .00005 & .000 & .2999 & .3002 \\
\hline & & 2013 & $.10001^{*}$ & .00005 & .000 & .0999 & .1002 \\
\hline \multirow{6}{*}{$\begin{array}{l}\text { Participatory } \\
\text { approach }\end{array}$} & \multirow[t]{2}{*}{2008} & 2013 & $-.20001^{*}$ & .00005 & .000 & -.2002 & -.1999 \\
\hline & & 2018 & $-.30002^{*}$ & .00005 & .000 & -.3002 & -.2999 \\
\hline & \multirow[t]{2}{*}{2013} & 2008 & $.20001^{*}$ & .00005 & .000 & .1999 & .2002 \\
\hline & & 2018 & $-.10001^{*}$ & .00005 & .000 & -.1002 & -.0999 \\
\hline & \multirow[t]{2}{*}{2018} & 2008 & $.30002^{*}$ & .00005 & .000 & .2999 & .3002 \\
\hline & & 2013 & $.10001^{*}$ & .00005 & .000 & .0999 & .1002 \\
\hline \multirow{6}{*}{$\begin{array}{l}\text { Access to drinking } \\
\text { water \& toilets }\end{array}$} & \multirow[t]{2}{*}{2008} & 2013 & $-19.30097^{*}$ & .00620 & .000 & -19.3207 & -19.2812 \\
\hline & & 2018 & $-29.30146^{*}$ & .00620 & .000 & -29.3212 & -29.2817 \\
\hline & \multirow[t]{2}{*}{2013} & 2008 & $19.30097^{*}$ & .00620 & .000 & 19.2812 & 19.3207 \\
\hline & & 2018 & $-10.00050^{*}$ & .00620 & .000 & -10.0202 & -9.9808 \\
\hline & \multirow[t]{2}{*}{2018} & 2008 & $29.30146^{*}$ & .00620 & .000 & 29.2817 & 29.3212 \\
\hline & & 2013 & $10.00050^{*}$ & .00620 & .000 & 9.9808 & 10.0202 \\
\hline \multirow{6}{*}{$\begin{array}{l}\text { Landless } \\
\text { representation } \\
\text { VWC }\end{array}$} & \multirow[t]{2}{*}{2008} & 2013 & .00000 & .00001 & 1.000 & .0000 & .0000 \\
\hline & & 2018 & $-.25001^{*}$ & .00001 & .000 & -.2500 & -.2500 \\
\hline & \multirow[t]{2}{*}{2013} & 2008 & .00000 & .00001 & 1.000 & .0000 & .0000 \\
\hline & & 2018 & $-.25001^{*}$ & .00001 & .000 & -.2500 & -.2500 \\
\hline & \multirow[t]{2}{*}{2018} & 2008 & $.25001^{*}$ & .00001 & .000 & .2500 & .2500 \\
\hline & & 2013 & $.25001^{*}$ & .00001 & .000 & .2500 & .2500 \\
\hline \multirow{6}{*}{$\begin{array}{l}\text { SC-ST-NT-OBC rep. } \\
\text { in VWC }\end{array}$} & \multirow[t]{2}{*}{2008} & 2013 & .00000 & .00301 & 1.000 & -.0096 & .0096 \\
\hline & & 2018 & $-1.09451^{*}$ & .00301 & .000 & -1.1041 & -1.0849 \\
\hline & \multirow[t]{2}{*}{2013} & 2008 & .00000 & .00301 & 1.000 & -.0096 & .0096 \\
\hline & & 2018 & $-1.09451^{*}$ & .00301 & .000 & -1.1041 & -1.0849 \\
\hline & \multirow[t]{2}{*}{2018} & 2008 & $1.09451^{*}$ & .00301 & .000 & 1.0849 & 1.1041 \\
\hline & & 2013 & $1.09451^{*}$ & .00301 & .000 & 1.0849 & 1.1041 \\
\hline \multirow{6}{*}{$\begin{array}{l}\% \text { Women } \\
\text { representation in } \\
\text { village Institutions }\end{array}$} & \multirow[t]{2}{*}{2008} & 2013 & $-1.96049^{*}$ & .00181 & .000 & -1.9662 & -1.9547 \\
\hline & & 2018 & $-6.47062^{*}$ & .00181 & .000 & -6.4764 & -6.4649 \\
\hline & \multirow[t]{2}{*}{2013} & 2008 & $1.96049^{*}$ & .00181 & .000 & 1.9547 & 1.9662 \\
\hline & & 2018 & $-4.51013^{*}$ & .00181 & .000 & -4.5159 & -4.5044 \\
\hline & \multirow[t]{2}{*}{2018} & 2008 & $6.47062^{*}$ & .00181 & .000 & 6.4649 & 6.4764 \\
\hline & & 2013 & $4.51013^{*}$ & .00181 & .000 & 4.5044 & 4.5159 \\
\hline \multirow[t]{6}{*}{ Literacy Rate } & \multirow[t]{2}{*}{2008} & 2013 & $-2.00010^{*}$ & .00665 & .000 & -2.0213 & -1.9789 \\
\hline & & 2018 & $-4.00020^{*}$ & .00665 & .000 & -4.0214 & -3.9790 \\
\hline & \multirow[t]{2}{*}{2013} & 2008 & $2.00010^{*}$ & .00665 & .000 & 1.9789 & 2.0213 \\
\hline & & 2018 & $-2.00010^{*}$ & .00665 & .000 & -2.0213 & -1.9789 \\
\hline & \multirow[t]{2}{*}{2018} & 2008 & $4.00020^{*}$ & .00665 & .000 & 3.9790 & 4.0214 \\
\hline & & 2013 & $2.00010^{*}$ & .00665 & .000 & 1.9789 & 2.0213 \\
\hline \multirow{2}{*}{$\begin{array}{l}\text { Conflict Management } \\
\text { Capabilities }\end{array}$} & 2008 & 2013 & $-.20001^{*}$ & .00005 & .000 & -.2002 & -.1998 \\
\hline & & 2018 & $-.20001^{*}$ & .00005 & .000 & -.2002 & -.1998 \\
\hline
\end{tabular}




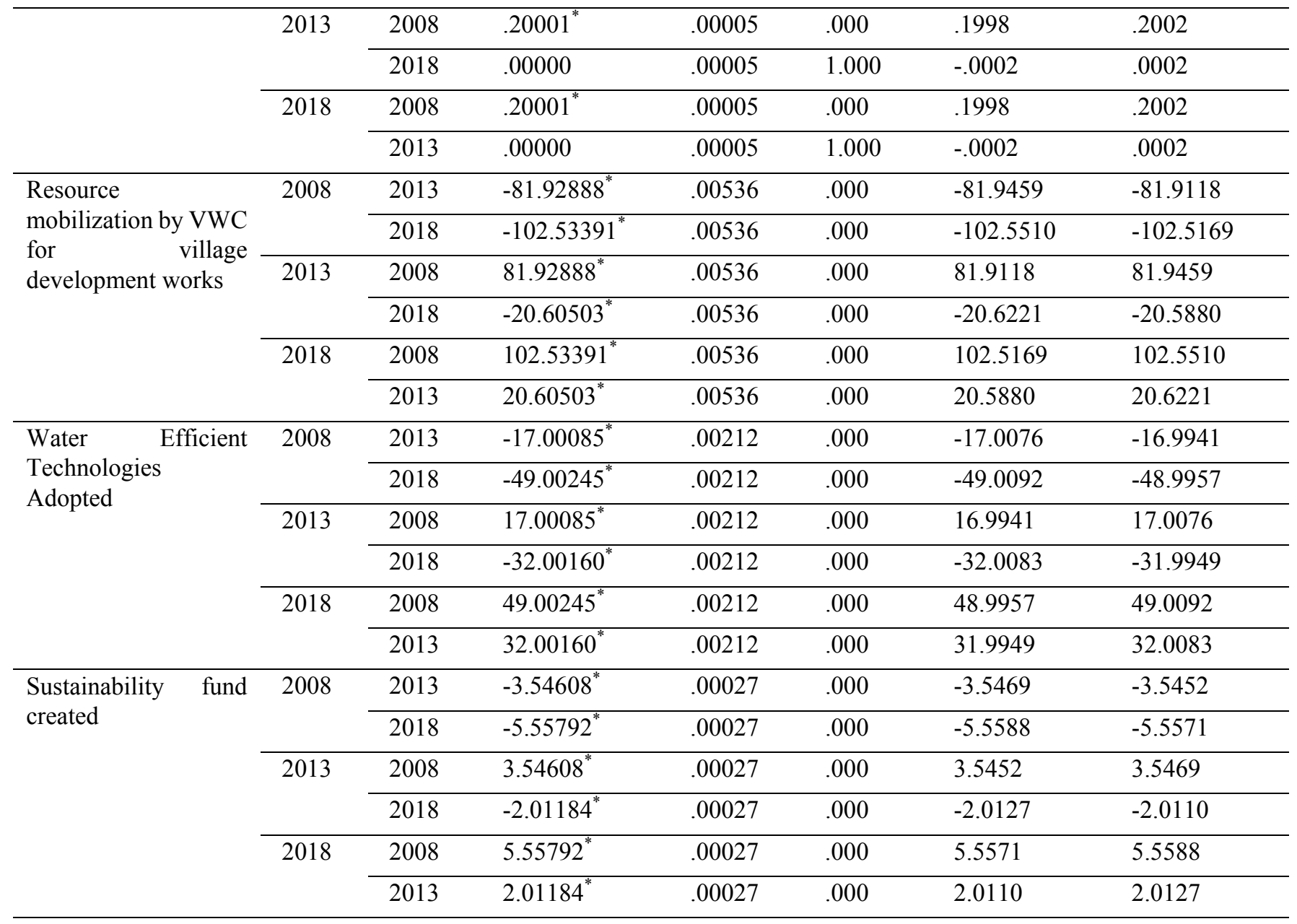

*. The mean difference is significant at the 0.05 level.

Table B3: ANOVA (Analysis of Variance) for Economic Parameters

\begin{tabular}{|c|c|c|c|c|c|c|}
\hline \multicolumn{7}{|l|}{ ANOVA } \\
\hline & & $\begin{array}{l}\text { Sum } \\
\text { Squares }\end{array}$ & of $\quad d f$ & Mean Square & $\mathbf{F}$ & Sig. \\
\hline \multirow[t]{3}{*}{ HH Average income } & Between Groups & .604 & 2 & .302 & 30861450.637 & .000 \\
\hline & Within Groups & .000 & 3 & .000 & & \\
\hline & Total & .604 & 5 & & & \\
\hline \multirow[t]{3}{*}{$\% \mathrm{HH}$ benefitted } & Between Groups & 2475.456 & 2 & 1237.728 & $\begin{array}{l}165136888.25 \\
8\end{array}$ & .000 \\
\hline & Within Groups & .000 & 3 & .000 & & \\
\hline & Total & 2475.456 & 5 & & & \\
\hline \multirow{3}{*}{$\begin{array}{l}\% \text { Reduction in } \\
\text { migration (from } \\
\text { base levels in 2008) }\end{array}$} & Between Groups & 3734.078 & 2 & 1867.039 & 292692512.707 & .000 \\
\hline & Within Groups & .000 & 3 & .000 & & \\
\hline & Total & 3734.078 & 5 & & & \\
\hline \multirow{3}{*}{$\begin{array}{l}\text { Dairy } \\
\text { Population }\end{array}$} & Between Groups & 9002.233 & 2 & 4501.117 & 5639119.193 & .000 \\
\hline & Within Groups & .002 & 3 & .001 & & \\
\hline & Total & 9002.236 & 5 & & & \\
\hline
\end{tabular}




\begin{tabular}{|c|c|c|c|c|c|c|}
\hline \multirow[t]{3}{*}{ Cropping Intensity } & Between Groups & 2136.456 & 2 & 1068.228 & 9216487.750 & .000 \\
\hline & Within Groups & .000 & 3 & .000 & & \\
\hline & Total & 2136.456 & 5 & & & \\
\hline \multirow[t]{3}{*}{ No. of crops grown } & Between Groups & 33.337 & 2 & 16.668 & 44448889.000 & .000 \\
\hline & Within Groups & .000 & 3 & .000 & & \\
\hline & Total & 33.337 & 5 & & & \\
\hline \multirow{3}{*}{$\begin{array}{l}\text { Quantity } \\
\text { collection }\end{array}$} & Between Groups & 1773877.374 & 2 & 886938.687 & 96111688.768 & .000 \\
\hline & Within Groups & .028 & 3 & .009 & & \\
\hline & Total & 1773877.402 & 5 & & & \\
\hline \multirow[t]{3}{*}{$\begin{array}{l}\text { Per HH credit } \\
\text { availed }\end{array}$} & Between Groups & $\begin{array}{l}1600579752.5 \\
0\end{array}$ & 2 & $\begin{array}{l}800289876.25 \\
4\end{array}$ & $\begin{array}{l}101347223.34 \\
8\end{array}$ & .000 \\
\hline & Within Groups & 23.690 & 3 & 7.897 & & \\
\hline & Total & $\begin{array}{l}1600579776.1 \\
9\end{array}$ & 5 & & & \\
\hline
\end{tabular}

Inference: All parameters are significantly different at $\alpha=0.05$ level.

Table B4: Comparison of parameter change between years 2008-2013-2018

\begin{tabular}{|c|c|c|c|c|c|c|c|}
\hline \multicolumn{8}{|c|}{ Multiple Comparisons } \\
\hline \multicolumn{8}{|l|}{$\begin{array}{l}\text { LSD } \\
\end{array}$} \\
\hline \multirow[t]{2}{*}{ Dependent Variable } & \multirow{2}{*}{$\begin{array}{l}\text { (I) } \\
\text { year }\end{array}$} & \multirow{2}{*}{$\begin{array}{l}(\mathrm{J}) \\
\text { year }\end{array}$} & \multirow{2}{*}{$\begin{array}{l}\text { Mean } \\
\text { Difference } \\
(\mathrm{I}-\mathrm{J})\end{array}$} & \multirow{2}{*}{$\begin{array}{l}\text { Std. } \\
\text { Error }\end{array}$} & \multirow[t]{2}{*}{ Sig. } & \multicolumn{2}{|c|}{$95 \%$ Confidence Interval } \\
\hline & & & & & & $\begin{array}{l}\text { Lower } \\
\text { Bound }\end{array}$ & Upper Bound \\
\hline \multirow[t]{6}{*}{ HH Average income } & 2008 & 2013 & $-.38873^{*}$ & .00010 & .000 & -.3890 & -.3884 \\
\hline & & 2018 & $-.77746^{*}$ & .00010 & .000 & -.7778 & -.7771 \\
\hline & 2013 & 2008 & $.38873^{*}$ & .00010 & .000 & .3884 & .3890 \\
\hline & & 2018 & $-.38873^{*}$ & .00010 & .000 & -.3890 & -.3884 \\
\hline & 2018 & 2008 & $.77746^{*}$ & .00010 & .000 & .7771 & .7778 \\
\hline & & 2013 & $.38873^{*}$ & .00010 & .000 & .3884 & .3890 \\
\hline \multirow[t]{6}{*}{$\% \mathrm{HH}$ benefitted } & 2008 & 2013 & $-6.75654^{*}$ & .00274 & .000 & -6.7653 & -6.7478 \\
\hline & & 2018 & $-46.06730^{*}$ & .00274 & .000 & -46.0760 & -46.0586 \\
\hline & 2013 & 2008 & $6.75654^{*}$ & .00274 & .000 & 6.7478 & 6.7653 \\
\hline & & 2018 & $-39.31077^{*}$ & .00274 & .000 & -39.3195 & -39.3021 \\
\hline & 2018 & 2008 & $46.06730^{*}$ & .00274 & .000 & 46.0586 & 46.0760 \\
\hline & & 2013 & $39.31077^{*}$ & .00274 & .000 & 39.3021 & 39.3195 \\
\hline \multirow[t]{6}{*}{$\begin{array}{l}\% \text { reduction } \\
\text { migration }\end{array}$} & 2008 & 2013 & $-17.29086^{*}$ & .00253 & .000 & -17.2989 & -17.2828 \\
\hline & & 2018 & $-59.40297 *$ & .00253 & .000 & -59.4110 & -59.3949 \\
\hline & 2013 & 2008 & $17.29086^{*}$ & .00253 & .000 & 17.2828 & 17.2989 \\
\hline & & 2018 & $-42.11211^{*}$ & .00253 & .000 & -42.1201 & -42.1041 \\
\hline & 2018 & 2008 & $59.40297 *$ & .00253 & .000 & 59.3949 & 59.4110 \\
\hline & & 2013 & $42.11211^{*}$ & .00253 & .000 & 42.1041 & 42.1201 \\
\hline animal & 2008 & 2013 & $-71.00355^{*}$ & .02825 & .000 & -71.0935 & -70.9136 \\
\hline
\end{tabular}




\begin{tabular}{|c|c|c|c|c|c|c|c|}
\hline \multicolumn{8}{|l|}{ Population } \\
\hline & & 2018 & $-90.00450^{*}$ & .02825 & .000 & -90.0944 & -89.9146 \\
\hline & 2013 & 2008 & $71.00355^{*}$ & .02825 & .000 & 70.9136 & 71.0935 \\
\hline & & 2018 & $-19.00095^{*}$ & .02825 & .000 & -19.0909 & -18.9110 \\
\hline & 2018 & 2008 & $90.00450^{*}$ & .02825 & .000 & 89.9146 & 90.0944 \\
\hline & & 2013 & $19.00095^{*}$ & .02825 & .000 & 18.9110 & 19.0909 \\
\hline \multirow[t]{6}{*}{ Cropping Intensity } & 2008 & 2013 & $-35.46225^{*}$ & .01077 & .000 & -35.4965 & -35.4280 \\
\hline & & 2018 & $-43.40530^{*}$ & .01077 & .000 & -43.4396 & -43.3710 \\
\hline & 2013 & 2008 & $35.46225^{*}$ & .01077 & .000 & 35.4280 & 35.4965 \\
\hline & & 2018 & $-7.94305^{*}$ & .01077 & .000 & -7.9773 & -7.9088 \\
\hline & 2018 & 2008 & $43.40530^{*}$ & .01077 & .000 & 43.3710 & 43.4396 \\
\hline & & 2013 & $7.94305^{*}$ & .01077 & .000 & 7.9088 & 7.9773 \\
\hline \multirow[t]{6}{*}{ Crop Diversity } & 2008 & 2013 & $-5.00025^{*}$ & .00061 & .000 & -5.0022 & -4.9983 \\
\hline & & 2018 & $-5.00025^{*}$ & .00061 & .000 & -5.0022 & -4.9983 \\
\hline & 2013 & 2008 & $5.00025^{*}$ & .00061 & .000 & 4.9983 & 5.0022 \\
\hline & & 2018 & .00000 & .00061 & 1.000 & -.0019 & .0019 \\
\hline & 2018 & 2008 & $5.00025^{*}$ & .00061 & .000 & 4.9983 & 5.0022 \\
\hline & & 2013 & .00000 & .00061 & 1.000 & -.0019 & .0019 \\
\hline \multirow{6}{*}{$\begin{array}{l}\text { Quantity } \\
\text { collection }\end{array}$} & 2008 & 2013 & $-605.03025^{*}$ & .09606 & .000 & -605.3360 & -604.7245 \\
\hline & & 2018 & $-1330.06650^{*}$ & .09606 & .000 & -1330.3722 & -1329.7608 \\
\hline & 2013 & 2008 & $605.03025^{*}$ & .09606 & .000 & 604.7245 & 605.3360 \\
\hline & & 2018 & $-725.03625^{*}$ & .09606 & .000 & -725.3420 & -724.7305 \\
\hline & 2018 & 2008 & $1330.06650^{*}$ & .09606 & .000 & 1329.7608 & 1330.3722 \\
\hline & & 2013 & $725.03625^{*}$ & .09606 & .000 & 724.7305 & 725.3420 \\
\hline \multirow[t]{6}{*}{ Per HH credit availed } & 2008 & 2013 & * 20003.62313 & 2.81007 & .000 & -20012.5660 & -19994.6802 \\
\hline & & 2018 & -40007.24625 & 2.81007 & .000 & -40016.1892 & -39998.3033 \\
\hline & 2013 & 2008 & $20003.62313^{*}$ & 2.81007 & .000 & 19994.6802 & 20012.5660 \\
\hline & & 2018 & -20003.62313 & 2.81007 & .000 & -20012.5660 & -19994.6802 \\
\hline & 2018 & 2008 & $40007.24625^{*}$ & 2.81007 & .000 & 39998.3033 & 40016.1892 \\
\hline & & 2013 & $20003.62313^{*}$ & 2.81007 & .000 & 19994.6802 & 20012.5660 \\
\hline
\end{tabular}


Table B5: ANOVA (Analysis of Variance) for Ecological Parameters

\begin{tabular}{|c|c|c|c|c|c|c|}
\hline \multicolumn{7}{|l|}{ ANOVA } \\
\hline & & $\begin{array}{ll}\text { Sum } & 0 \\
\text { Squares } & \end{array}$ & $\mathrm{df}$ & Mean Square & $\mathrm{F}$ & Sig. \\
\hline \multirow{3}{*}{$\begin{array}{l}\% \text { of Private Waste } \\
\text { Lands brought under } \\
\text { cultivation }\end{array}$} & Between Groups & 6554.800 & 2 & 3277.400 & 200101415.215 & .000 \\
\hline & Within Groups & .000 & 3 & .000 & & \\
\hline & Total & 6554.800 & 5 & & & \\
\hline \multirow[t]{3}{*}{ \% Check dams good } & Between Groups & 367.524 & 2 & 183.762 & 5145569.094 & .000 \\
\hline & Within Groups & .000 & 3 & .000 & & \\
\hline & Total & 367.524 & 5 & & & \\
\hline \multirow{3}{*}{$\begin{array}{l}\text { Water } \\
\text { capacity }\end{array}$} & Between Groups & 552902.205 & 2 & 276451.102 & 88528538.656 & .000 \\
\hline & Within Groups & .009 & 3 & .003 & & \\
\hline & Total & 552902.214 & 5 & & & \\
\hline \multirow[t]{3}{*}{ irrigated in } & Between Groups & 29289.262 & 2 & 14644.631 & $\begin{array}{l}117389479.32 \\
9\end{array}$ & .000 \\
\hline & Within Groups & .000 & 3 & .000 & & \\
\hline & Total & 29289.262 & 5 & & & \\
\hline \multirow{3}{*}{$\begin{array}{l}\text { Area under } \\
\text { efficient } \\
\text { technologies }\end{array}$} & Between Groups & 2476.248 & 2 & 1238.124 & $\begin{array}{l}276161443.07 \\
0\end{array}$ & .000 \\
\hline & Within Groups & .000 & 3 & .000 & & \\
\hline & Total & 2476.248 & 5 & & & \\
\hline \multirow{3}{*}{$\begin{array}{l}\text { Average static water } \\
\text { level in wells }\end{array}$} & Between Groups & 5.395 & 2 & 2.698 & 24094495.557 & .000 \\
\hline & Within Groups & .000 & 3 & .000 & & \\
\hline & Total & 5.395 & 5 & & & \\
\hline \multirow{3}{*}{$\begin{array}{l}\text { Area } \\
\text { cover }\end{array}$} & Between Groups & 26291.962 & 2 & 13145.981 & 76372399.734 & .000 \\
\hline & Within Groups & .001 & 3 & .000 & & \\
\hline & Total & 26291.963 & 5 & & & \\
\hline
\end{tabular}

Inference above ANOVA: All parameters are significantly different at $\alpha=0.05$ level.

Following Table gives the comparison of ecological sustainability parameters across three different years i.e. the year of start of project 2008, the year of project completion 2013 and the year of study 2018. 
Table B6: Comparison of parameter change between years 2008-2013-2018

\begin{tabular}{|c|c|c|c|c|c|c|c|}
\hline \multicolumn{8}{|l|}{ Multiple Comparisons } \\
\hline \multicolumn{8}{|l|}{ LSD } \\
\hline \multirow[t]{2}{*}{ Dependent Variable } & \multirow{2}{*}{$\begin{array}{l}\text { (I) } \\
\text { year }\end{array}$} & \multirow{2}{*}{$\begin{array}{l}(\mathrm{J}) \\
\text { year }\end{array}$} & \multirow{2}{*}{$\begin{array}{l}\text { Mean } \\
\text { Difference } \\
(\mathrm{I}-\mathrm{J})\end{array}$} & \multirow{2}{*}{$\begin{array}{l}\text { Std. } \\
\text { Error }\end{array}$} & \multirow[t]{2}{*}{ Sig. } & \multicolumn{2}{|c|}{$95 \%$ Confidence Interval } \\
\hline & & & & & & $\begin{array}{l}\text { Lower } \\
\text { Bound }\end{array}$ & Upper Bound \\
\hline \multirow{6}{*}{$\begin{array}{l}\% \text { of Private Waste } \\
\text { Lands brought under } \\
\text { cultivation }\end{array}$} & \multirow[t]{2}{*}{2008} & 2013 & $-69.09345^{*}$ & .00405 & .000 & -69.1063 & -69.0806 \\
\hline & & 2018 & $-71.09355^{*}$ & .00405 & .000 & -71.1064 & -71.0807 \\
\hline & \multirow[t]{2}{*}{2013} & 2008 & $69.09345^{*}$ & .00405 & .000 & 69.0806 & 69.1063 \\
\hline & & 2018 & $-2.00010^{*}$ & .00405 & .000 & -2.0130 & -1.9872 \\
\hline & \multirow[t]{2}{*}{2018} & 2008 & $71.09355^{*}$ & .00405 & .000 & 71.0807 & 71.1064 \\
\hline & & 2013 & $2.00010^{*}$ & .00405 & .000 & 1.9872 & 2.0130 \\
\hline \multirow[t]{6}{*}{$\%$ Check dams good } & \multirow[t]{2}{*}{2008} & 2013 & $8.33375^{*}$ & .00598 & .000 & 8.3147 & 8.3528 \\
\hline & & 2018 & $-10.78485^{*}$ & .00598 & .000 & -10.8039 & -10.7658 \\
\hline & \multirow[t]{2}{*}{2013} & 2008 & $-8.33375^{*}$ & .00598 & .000 & -8.3528 & -8.3147 \\
\hline & & 2018 & $-19.11860^{*}$ & .00598 & .000 & -19.1376 & -19.0996 \\
\hline & \multirow[t]{2}{*}{2018} & 2008 & $10.78485^{*}$ & .00598 & .000 & 10.7658 & 10.8039 \\
\hline & & 2013 & $19.11860^{*}$ & .00598 & .000 & 19.0996 & 19.1376 \\
\hline \multirow{6}{*}{$\begin{array}{l}\text { Water } \\
\text { capacity }\end{array}$} & \multirow[t]{2}{*}{2008} & 2013 & $-5.31877^{*}$ & .05588 & .000 & -5.4966 & -5.1409 \\
\hline & & 2018 & $-646.59683^{*}$ & .05588 & .000 & -646.7747 & -646.4190 \\
\hline & \multirow[t]{2}{*}{2013} & 2008 & $5.31877^{*}$ & .05588 & .000 & 5.1409 & 5.4966 \\
\hline & & 2018 & $-641.27806^{*}$ & .05588 & .000 & -641.4559 & -641.1002 \\
\hline & \multirow[t]{2}{*}{2018} & 2008 & $646.59683^{*}$ & .05588 & .000 & 646.4190 & 646.7747 \\
\hline & & 2013 & $641.27806^{*}$ & .05588 & .000 & 641.1002 & 641.4559 \\
\hline \multirow[t]{6}{*}{ Area irrigated in Rabi } & \multirow[t]{2}{*}{2008} & 2013 & $-117.50587^{*}$ & .01117 & .000 & -117.5414 & -117.4703 \\
\hline & & 2018 & $-166.50832^{*}$ & .01117 & .000 & -166.5439 & -166.4728 \\
\hline & \multirow[t]{2}{*}{2013} & 2008 & $117.50587^{*}$ & .01117 & .000 & 117.4703 & 117.5414 \\
\hline & & 2018 & $-49.00245^{*}$ & .01117 & .000 & -49.0380 & -48.9669 \\
\hline & \multirow[t]{2}{*}{2018} & 2008 & $166.50832^{*}$ & .01117 & .000 & 166.4728 & 166.5439 \\
\hline & & 2013 & $49.00245^{*}$ & .01117 & .000 & 48.9669 & 49.0380 \\
\hline \multirow{6}{*}{$\begin{array}{l}\text { Area under water } \\
\text { efficient technologies }\end{array}$} & 2008 & 2013 & $-17.00085^{*}$ & .00212 & .000 & -17.0076 & -16.9941 \\
\hline & & 2018 & $-49.00245^{*}$ & .00212 & .000 & -49.0092 & -48.9957 \\
\hline & 2013 & 2008 & $17.00085^{*}$ & .00212 & .000 & 16.9941 & 17.0076 \\
\hline & & 2018 & $-32.00160^{*}$ & .00212 & .000 & -32.0083 & -31.9949 \\
\hline & 2018 & 2008 & $49.00245^{*}$ & .00212 & .000 & 48.9957 & 49.0092 \\
\hline & & 2013 & $32.00160^{*}$ & .00212 & .000 & 31.9949 & 32.0083 \\
\hline Average static water & 2008 & 2013 & $-1.95207^{*}$ & .00033 & .000 & -1.9531 & -1.9510 \\
\hline level in wells & & 2018 & $-2.06624^{*}$ & .00033 & .000 & -2.0673 & -2.0652 \\
\hline & 2013 & 2008 & $1.95207^{*}$ & .00033 & .000 & 1.9510 & 1.9531 \\
\hline & & 2018 & $-.11417^{*}$ & .00033 & .000 & -.1152 & -.1131 \\
\hline & 2018 & 2008 & $2.06624^{*}$ & .00033 & .000 & 2.0652 & 2.0673 \\
\hline
\end{tabular}




\begin{tabular}{|c|c|c|c|c|c|c|c|}
\hline & & 2013 & $.11417^{*}$ & .00033 & .000 & .1131 & .1152 \\
\hline \multirow[t]{6}{*}{ Area vegetative cover } & 2008 & 2013 & $-52.00260^{*}$ & .01312 & .000 & -52.0444 & -51.9608 \\
\hline & & 2018 & $-159.00795^{*}$ & .01312 & .000 & -159.0497 & -158.9662 \\
\hline & 2013 & 2008 & $52.00260^{*}$ & .01312 & .000 & 51.9608 & 52.0444 \\
\hline & & 2018 & $-107.00535^{*}$ & .01312 & .000 & -107.0471 & -106.9636 \\
\hline & 2018 & 2008 & $159.00795^{*}$ & .01312 & .000 & 158.9662 & 159.0497 \\
\hline & & 2013 & $107.00535^{*}$ & .01312 & .000 & 106.9636 & 107.0471 \\
\hline
\end{tabular}

*. The mean difference is significant at the 0.05 level.

\section{Inference}

The ANOVA shows that the change in all the parameters between year 2008 and 2013 is highly significant at $\alpha=$ 0.05 level. Similarly, the change between the year 2008 and 2018 as well as between 2013 and 2018 is also highly significant.

\section{Copyrights}

Copyright for this article is retained by the author(s), with first publication rights granted to the journal.

This is an open-access article distributed under the terms and conditions of the Creative Commons Attribution license (http://creativecommons.org/licenses/by/4.0/). 